\title{
EFFECT OF INTERMETALLIC PHASES ON CORROSION BEHAVIOR AND MECHANICAL PROPERTIES OF DUPLEX STAINLESS STEEL AND SUPER-DUPLEX STAINLESS STEEL
}

\author{
Prabhu Paulraj', Rajnish Garg ${ }^{1}$ \\ 1 University of Petroleum \& Energy Studies, Dehradun 248007, Uttarakhand, India, e-mail: paulrajprabhu1@ \\ gmail.com
}

Received: 2015.07.18

Accepted: 2015.08.05

Published: 2015.09.01

\begin{abstract}
Duplex Stainless Steels (DSS) and Super Duplex Stainless Steel (SDSS) have excellent integration of mechanical and corrosion properties. However, the formation of intermetallic phases is a major problem in their usage. The mechanical and corrosion properties are deteriorated due to the presence of intermetallic phases. These phases are induced during welding, prolonged exposure to high temperatures, and improper heat treatments. The main emphasis of this review article is on intermetallic phases and their effects on corrosion and mechanical properties. First the effect of various alloying elements on DSS and SDSS has been discussed followed by formation of various intermetallic phases. The intermetallic phases affect impact toughness and corrosion resistance significantly. Their deleterious effect on weldments has also been reviewed.
\end{abstract}

Keywords: stainless steel, intermetallic phases, corrosion, mechanical properties, welding.

\section{INTRODUCTION}

Duplex stainless steels $(22 \% \mathrm{Cr})$ and Super Duplex Stainless Steels $(25 \% \mathrm{Cr})$ are a family of steels having a combination of excellent corrosion resistance and mechanical properties. They are defined by their balanced ferritic-austenitic microstructure, often referred as micro-duplex structure. They offer higher toughness and better weldability than pure ferritic stainless steels and higher strength, better corrosion resistance than pure austenitic stainless steels [1-4]. Hence they are attractive material for applications where these properties are desired like in off-shore industries, food industries, chemical industries, paper industries [5, 6], nuclear industries $[7,8]$ and in structural applications as well $[9,10]$. DSS can be also used as a material for water tankers to supply fresh drinking water in military areas where fresh water is scarce [11]. DSS and SDSS can replace high strength steels and austenitic steels in various applications such as construction of military vehicles, transportation in critical military areas, fabrication of armour steels [12, 13], marine, oil \& Gas and offshore industries.

Chemical composition of DSS and SDSS materials are given in Table 1.

The section at $70 \%$ iron, ternary phase diagram representing duplex stainless steels is shown in Figure 1 [14]. They are solidified to ferrite at high temperatures. At low temperatures they are converted to duplex structures.

Despite of their attractive properties, some solid-state transformations occur at high tem-

Table 1. Chemical compositions of DSS and SDSS in weight percentage

\begin{tabular}{|c|c|c|c|c|c|c|c|c|}
\hline Material & $\mathrm{C}$ & $\mathrm{N}$ & $\mathrm{Mn}$ & $\mathrm{Cr}$ & $\mathrm{Mo}$ & $\mathrm{Ni}$ & $\mathrm{Cu}$ & $\mathrm{Fe}$ \\
\hline DSS & 0.02 & $0.14-0.20$ & 1.60 & $21.65-23.00$ & $2.56-3.5$ & $4.5-5.5$ & 0.43 & balance \\
\hline SDSS & 0.03 & $0.24-0.32$ & 1.20 & $24.0-26.0$ & $3.0-5.0$ & $6.0-8.00$ & 0.50 & balance \\
\hline
\end{tabular}




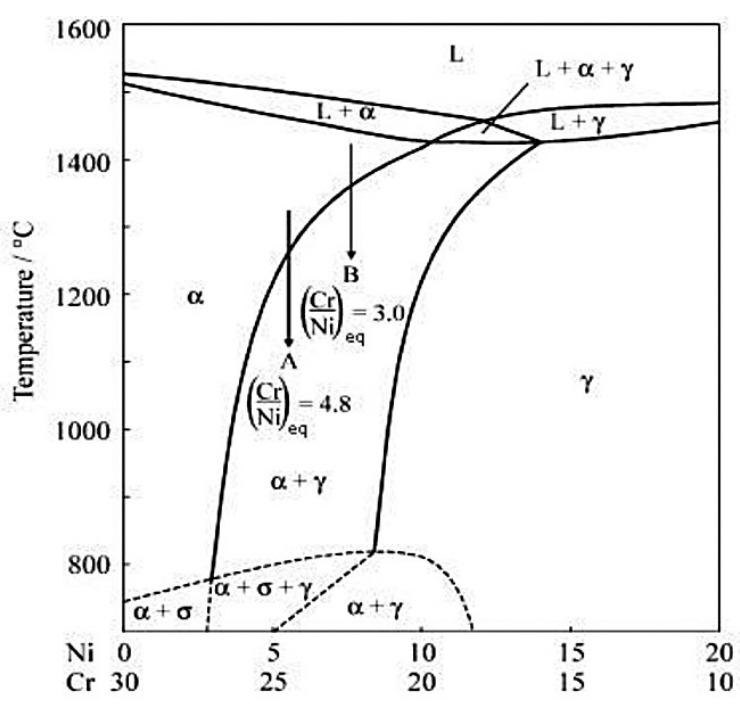

Fig. 1. Fe- $\mathrm{Cr}-\mathrm{Ni}$ system at $70 \% \mathrm{Fe}$ [14]

peratures which cause changes in mechanical and corrosion properties [15]. Formation of Sigma $(\sigma)$ phase, Chi $(\chi)$ phase, Chromium nitrides and carbides occurs between temperatures 500 to $1000{ }^{\circ} \mathrm{C}$ as shown in Figure 2 [16].

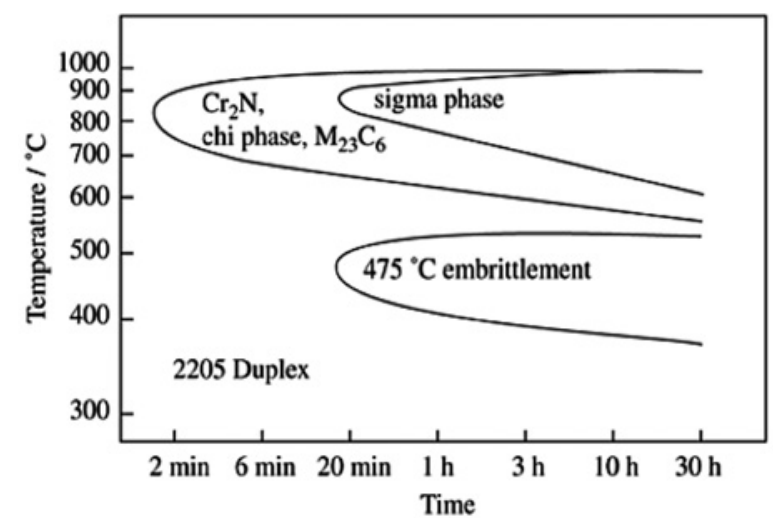

Fig. 2. Intermetallic phase precipitations for UNS S31803 DSS [16]

\section{Effect of alloying elements on properties of DSS and SDSS}

The major alloying elements in DSS and SDSS are chromium, molybdenum, nickel, nitrogen, copper, manganese etc.

\section{Chromium}

Chromium acts as a ferrite stabilizer [17]. The major function of $\mathrm{Cr}$ is to form a protective oxyhydroxide film which improves localized corrosion resistance. But there is a limit on addition of $\mathrm{Cr}$ to steels because higher $\mathrm{Cr}$ contents facilitates formation of detrimental intermetallic phases in duplex stainless steels [18]. The Cr equivalent in
DSS and SDSS is given by [19]:

$$
\mathrm{Cr}_{\text {eq }}=\% \mathrm{Cr}+\% \mathrm{Mo}+0.7 \cdot \% \mathrm{Nb}
$$

\section{Molybdenum}

Molybdenum is also a ferrite stabilizer [17]. It protects DSS and SDSS from pitting and crevice corrosion attack by forming immune oxy-hydroxide layer or molybdate ion. From Pitting Resistance Equivalent Number (PREN) equation, it is clear that Mo is 3.3 times effective than $\mathrm{Cr}$ when pitting is considered [20]. But high Mo contents might lead to formation of detrimental chi and sigma phase at high working temperatures [21].

\section{Nickel}

Nickel is an austenite stabilizer. The main function of $\mathrm{Ni}$ is to control phase balance and element partitioning. In order to maintain balance between ferrite and austenite, the ferrite stabilizers and austenite stabilizers need to be added in appropriate amount. The Ni equivalent is given by [19]:

$$
\mathrm{Ni}_{\text {eq }}=\% \mathrm{Ni}+35 \cdot \% \mathrm{C}+20 \cdot \% \mathrm{~N}+0.25 \cdot \% \mathrm{Cu}
$$

Nickel reduces current density values and push Electrode potential in noble direction [E6]. The high Ni content is desired for corrosion resistance in reducing atmospheres however, the high Ni content accelerates formation of prime- $\alpha$ phase in ferrite which leads to embrittlement of the material [18].

\section{Nitrogen}

Nitrogen is also an austenite stabilizer element. It increases pitting resistance, austenite content and strength of an alloy [23]. It has been also found that $\mathrm{N}$ increases crevice corrosion resistance. Nitrogen increases corrosion resistance in acid solutions but it does not have much effect in basic or neutral solutions [24]. It has favourable effects on corrosion resistance of DSS and SDSS as it delays the precipitation of intermetallic phases [25]. At the same time, the high $\mathrm{N}$ content causes nitrides precipitation.

\section{Manganese}

Addition of Mn to stainless steels increase the wear and abrasion resistance [18] as well as tensile strength without loss of ductility [26]. The high Mn content increases the temperature range and rate of formation of intermetallic phases. It also causes formation of MnS, which acts as an initiation site for formation of pits [27] thereby leading to a decrease in the pitting resistance [26]. 


\section{Copper}

Additions of copper to stainless steels is known to improve corrosion resistance in nonoxidizing environments like sulphuric acid. It is limited up to $2 \mathrm{Wt}$. \% otherwise it will reduce hot ductility of steels. Also, high $\mathrm{Cu}$ content causes reduction in pitting resistance due to formation of epsilon phase [28].

\section{Overview of various phases}

The various intermetallic phases that can occur in DSS and SDSS are tabulated in Table 2.

In DSS and SDSS, it is recommended to maintain ferrite to austenite balance. During welding this balance is disturbed due to ferritization at high temperatures associated with welding process. The high ferrite contents are not desirable as it makes the material prone to pitting attack. Hence, filler materials are generally manufactured with higher Ni contents (2-4\%) than the base material [30]. Sometimes post weld heat treatments (Solution annealing) are also preferred to retain the phase balance after welding [31]. The heat input and cooling rate in welding are important as they control ferrite to austenite transformation [30, 32]. The high heat input promotes precipitation of sigma phase, nitrides and carbides in heat affected zones [33]. The welding of high thickness parts with low heat input is avoided as it may form chromium nitrides [34]. The slow cooling forms more austenite but at the same time, it may cause precipitation of intermetallic phases. Hence, cooling rate is kept low enough to retain phase balance but high enough to avoid intermetallic phase formation [30]. Similar observations were also made by other researchers as they concluded that filler material with $4.7 \% \mathrm{Ni}$ is the best choice on the basis of economy and life of the weldments subjected to corrosive environments [35].

Table 2. Intermetallic phases, chemical formulae and their temperature range [29]

\begin{tabular}{|c|c|c|}
\hline $\begin{array}{c}\text { Intermetallic } \\
\text { phases }\end{array}$ & Chemical formula & $\begin{array}{c}\text { Temperature range } \\
\left({ }^{\circ} \mathrm{C}\right)\end{array}$ \\
\hline Sigma & $\mathrm{Fe}-\mathrm{Cr}-\mathrm{Mo}$ & $600-1000$ \\
\hline Chi & $\mathrm{Fe}_{36} \mathrm{Cr}_{12} \mathrm{Mo}_{10}$ & $700-900$ \\
\hline Nitrides & $\mathrm{CrN}_{\mathrm{Cr}} \mathrm{N}$ & $700-900$ \\
\hline Carbides & $\mathrm{M}_{7} \mathrm{C}_{3} / \mathrm{M}_{23} \mathrm{C}_{6}$ & $550-650$ \\
\hline $\mathrm{R}$ & $\mathrm{Fe}_{-} \mathrm{Cr}-\mathrm{Mo}$ & $550-800$ \\
\hline$\Pi$ & $\mathrm{Fe}_{7} \mathrm{Mo}_{13} \mathrm{~N}_{4}$ & $550-600$ \\
\hline $\begin{array}{c}\text { Prime alpha }\left(\alpha^{\prime}\right) \\
\text { phase }\end{array}$ & $\mathrm{Fe}-\mathrm{Cr}$ & 475 \\
\hline
\end{tabular}

Laser welding of UNS S32205 followed by low heat input surface treatment was reported. A numerical model on the possibility of intermetallic phase precipitation was proposed. The calculated cooling time for whole welding cycle was 30 to $40 \mathrm{~s}$ which is much lower than the precipitation time required for the formation of intermetallic phases determined from TTT diagram of UNS S32205 [36].

Some authors concluded that the intermetallic phases formed in welding are much more hazardous than the one which form in aging heat treatments. This could be attributed to complex grain structure and failure-prone heat affected zone in welding [37].

\section{Sigma phase}

Sigma phase is a Cr-Mo rich hard precipitate which occurs at temperatures between 600-1000 ${ }^{\circ} \mathrm{C}[38,39]$. The elements like $\mathrm{Cr}, \mathrm{Mo}, \mathrm{Ni}, \mathrm{Si}$ and Mn enhance the formation of Sigma phase. The diffusion of chromium in ferrite is a most significant thermodynamic process in formation of $\sigma$ phase [40]. Sigma $(\sigma)$ is non-magnetic, tetragonal crystalline structure with 30 atoms per cell [41]. This phase occurs due to Eutectoid reaction where ferrite is converted to Sigma $(\sigma)$ and secondary austenitic phase $\left(\gamma_{2}\right)$ [42].

$$
\alpha \rightarrow \gamma_{2}+\sigma
$$

At temperature between 850-900 ${ }^{\circ} \mathrm{C}$, sigma phase has fastest precipitation rate. Sigma phase precipitation starts at $\alpha / \alpha$ boundaries, $\alpha / \gamma$ boundaries as they are found to be high energy nucleation sites [43]. Later, Sigma phase grows into ferrite phase as the diffusion rate in ferrite phase is 100 times faster than that of austenite, which also makes it a favourable site for precipitation of all intermetallic phases [38].

The precipitation rate of Sigma phase differ with tempering [Heating from room temperature] and quenching [cooling from higher temperature] process as shown in Figure 3. Few authors concluded that tendency of formation of sigma phase in tempering is very high as compared to quenching process. This can be attributed to the cooling rate required in quenching to form sigma phase is below 1 $\mathrm{K} / \mathrm{s}$ [44]. The cooling rates in air for fabricated or welded parts of nominal thickness are much higher than $1 \mathrm{~K} / \mathrm{s}$. Hence sigma phase formation is not promoted.

The precipitation of sigma phase is inevitable in parts with large thickness [45]. The volume 


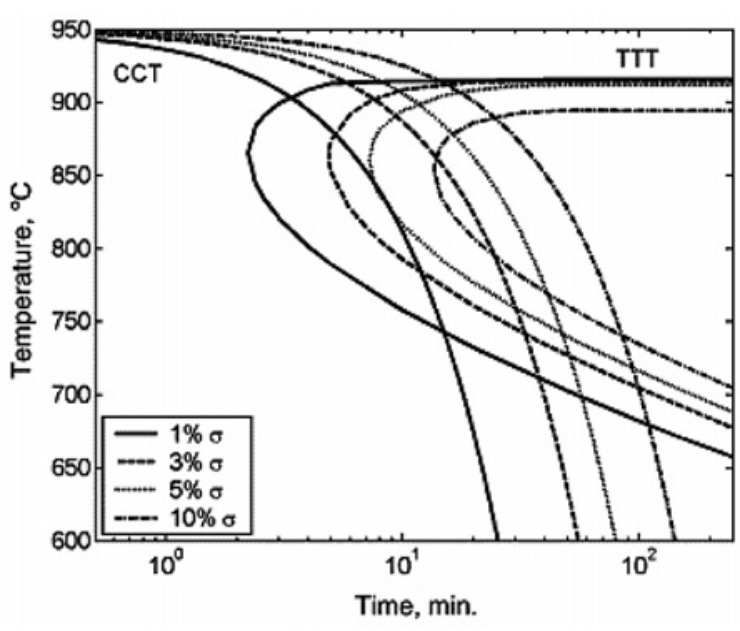

Fig. 3. CCT and TTT curves for sigma phase precipitation [39]

content of sigma can be minimized by increasing cooling rate or adjustment in chemical composition and. High cooling rate minimizes the chances of sigma phase formation [44].

\section{Chi phase $(\chi)$}

Chi phase formation takes place prior to sigma phase formation between temperatures $750-850{ }^{\circ} \mathrm{C}$. This phase is thermodynamically unstable. Chi phase $(\chi)$ forms on the ferrite/ferrite interface and grows into the ferrite [46]. The sigma phase formation takes place at the expense of Chi phase as shown in Figure 4 [46]. As Chiphase is richer in Mo than sigma phase and Mo being a heavy element, it is easy to contrast between sigma and chi phase using Back-Scattered Electron Microscope (BSE) [46, 47].
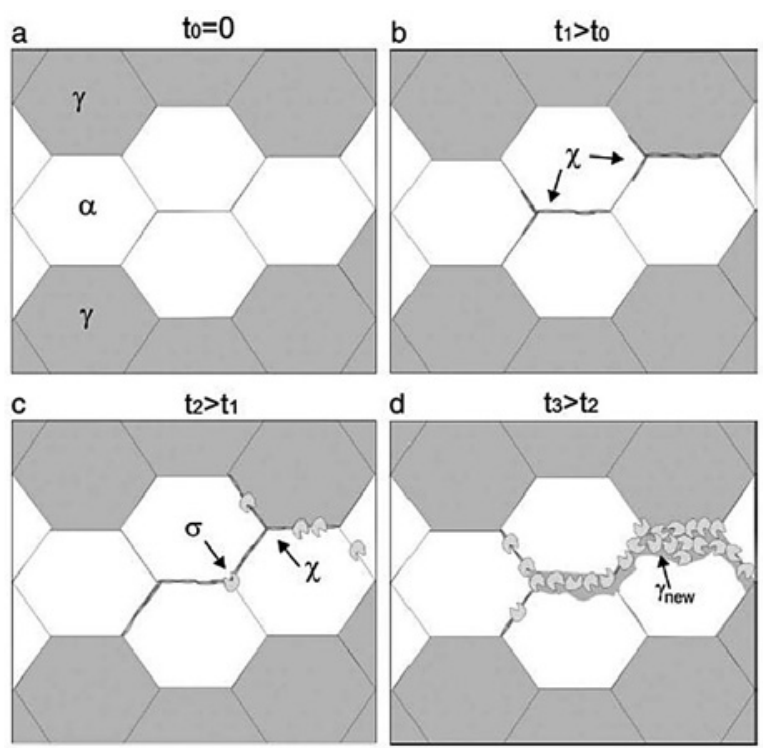

Fig. 4. Chi phase precipitation in DSS [46]

\section{Secondary austenite $\left(\gamma_{2}\right)$}

Secondary austenite forms with different mechanisms at different temperatures. Below $650{ }^{\circ} \mathrm{C}$ it shows a diffusion-less transformation similar to martensitic formation. Between $650-800{ }^{\circ} \mathrm{C}$, it is in the form of Widmanstatten austenite. Here the $\gamma_{2}$ formation follows Kurdjumov-Sachs orientation relationship and it takes place with diffusion phenomenon because of its Ni enrichment as compared to ferrite. This austenite is depleted in $\mathrm{Cr}$ and $\mathrm{N}$ as compared to primary austenite. In between 800$900{ }^{\circ} \mathrm{C}$, with eutectoid reaction $\gamma_{2}$ formation takes place [42]. In this reaction, $\gamma_{2}$ absorbs $\mathrm{Ni}$, which is austenite stabilizer and rejects $\mathrm{Cr}$ and Mo. This causes formation of $\mathrm{Cr}$, Mo rich precipitates like Sigma phase. As $\gamma_{2}$ is depleted in $\mathrm{Cr}$ and Mo, they are the favourable sites for pitting corrosion [48].

\section{Chromium nitrides $\left(\mathrm{CrN} / \mathrm{Cr}_{2} \mathrm{~N}\right)$}

Chromium nitrides precipitation is commonly found between temperatures $700-900{ }^{\circ} \mathrm{C}$, during fast cooling from high annealing temperatures. It is because of saturation of ferrite with nitrogen. At higher temperatures nitrogen partitioning increases in ferrite. But on cooling, solubility starts decreasing thus making ferrite saturated with nitrogen. This forms $\mathrm{Cr}_{2} \mathrm{~N}$ at intra-granular sites [49]. Another nitride, $\mathrm{CrN}$ forms during welding operations in the Heat affected zone.

\section{R-phase}

R-phase precipitates between temperatures $550-650^{\circ} \mathrm{C}$ in an initial stage of aging and later, disappears with aging time by transformation to Sigma phase [50]. They form at intra and inter granular sites. R-phase is Mo rich compound and their stability increases with increase in Mo content [50, 51].

\section{II-phase}

$\Pi$-phase formation takes place after isothermal heat treatment at $600^{\circ} \mathrm{C}$ for long aging time. This phase is often confused with Sigma phase as it is also rich in $\mathrm{Cr}$ and $\mathrm{Mo}$ [18].

\section{$\tau$-phase}

$\tau$-phase is a needle like structure which forms at ferrite/ferrite boundaries after heat treatment between $550-650{ }^{\circ} \mathrm{C}$ [52].

\section{Alpha Prime ( $\left.\alpha^{\prime}\right)$ phase}

A binary Fe-Cr alloy embrittles in temperature range of $280-500^{\circ} \mathrm{C}$. This embrittlement is 
caused by decomposition of ferrite phase into $\alpha$ phase (rich in iron) and $\alpha$ ' phase (rich in chromium). The presence of miscibility gap in $\mathrm{Fe}-\mathrm{Cr}$ phase diagram causes this embrittlement [53]. At $475{ }^{\circ} \mathrm{C}$, the rate of embrittlement is highest, hence this occurrence is known as $475^{\circ} \mathrm{C}$ embrittlement.

\section{EFFECT ON CORROSION PROPERTIES}

\section{Pitting corrosion}

Pitting is a localized phenomenon which leads to formation of small pits or holes on metal surface. Pitting is an autocatalytic process. It is initiated at surface defect which leads to formation of deep cavities in the metal. At the same time other surface remains defect free. Pit morphology is shown in Figure 5.

DSS are prone to pitting corrosion which largely depends on chemical composition of material, chloride concentrations, $\mathrm{pH}$ value and temperature of the corrosion media.

Pitting corrosion resistance is measured in terms of Pitting Resistance Equivalent Number (PREN) value which is given by:

$$
\begin{array}{lr}
\text { PREN }_{16}=\% C r+3.3 \cdot \% \mathrm{Mo}+16 \cdot \% \mathrm{~N} & {[55]} \\
\operatorname{PREN}_{20}=\% \mathrm{Cr}+3.3 \cdot \% \mathrm{Mo}+20 \cdot \% \mathrm{~N} & {[56]} \\
\text { PREN }_{30}=\% \mathrm{Cr}+3.3 \cdot \% \mathrm{Mo}+30 \cdot \% \mathrm{~N} & {[55]} \\
\text { PREW }=\% \mathrm{Cr}+3.3 \cdot[\% \mathrm{Mo}+0.5 \cdot \% \mathrm{~W}]+16 \cdot \% \mathrm{~N}[57]
\end{array}
$$

The PREN ${ }_{16}$ is used to correlate between pitting resistance and chemical composition. The

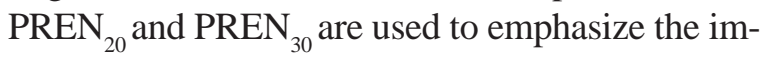
portance of nitrogen in resistance against pitting.

In a duplex microstructure, $\mathrm{Cr}$ and Mo partition to ferrite and $\mathrm{N}$ and $\mathrm{Ni}$ partition to austenite, results in different PREN values for two phases. Hence, the alloying elements should be in appropriate content to get similar PREN values. Hanninen et al. [23] observed the effect of nitrogen on pitting resistance. Generally austenite is more prone to pitting than ferrite, as the weight. $\%$ of $\mathrm{N}$ is not enough to get as high PREN value as ferrite. Therefore $\mathrm{N}$ content can be increased up to $0.4 \%$ to get higher PREN value. Beyond this limit, PREN for austenite increases but PREN for ferrite decreases. This is due to the fact that, $\mathrm{N}$ reduces partitioning ratio for $\mathrm{Cr}$, Mo in ferrite, leading to reduction in PREN value. Hence, adjustment of alloying elements is important to get equal PREN values for both phases.

Sigma $(\sigma)$ phase is rich in $\mathrm{Cr}$ and Mo content, which are ferrite stabilizers in DSS. The precipitation of $\sigma$ phase causes consumption of $\mathrm{Cr}$ and $\mathrm{Mo}$ from surrounding ferrite and austenite, which leads to reduction in corrosion resistance of DSS [58].

The Critical Pitting Temperature (CPT) is the lowest temperature at which stable pit formation is initiated. Park et al. [58] carried out a study on effect of sigma phase precipitation on DSS in $10 \% \mathrm{Fe}_{3} \mathrm{Cl} \cdot 6 \mathrm{H}_{2} \mathrm{O}$ solution. They allowed sigma phase precipitation by different aging treatments and found that CPT value decreases with increase in $\sigma$-phase precipitation. After sufficient aging time, $\sigma$-phase grew with depletion of $\mathrm{Cr}$ and $\mathrm{Mo}$ around it and corrosion resistant alloy became susceptible to metastable pitting. The effect of aging time on CPT is shown in Figure 6.

Pohl et al. [41] reported that with Eutectoid reaction $\alpha$-ferrite converts to sigma $(\sigma)$ and secondary austenitic phase $\left(\gamma_{2}\right)$. This $\gamma_{2}$ phase is depleted in $\mathrm{Cr}$ and Mo content which decreases the corrosion resistance. a)

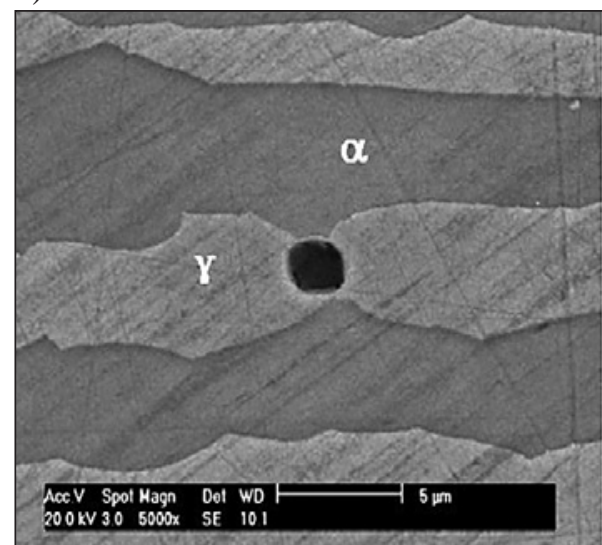

b)

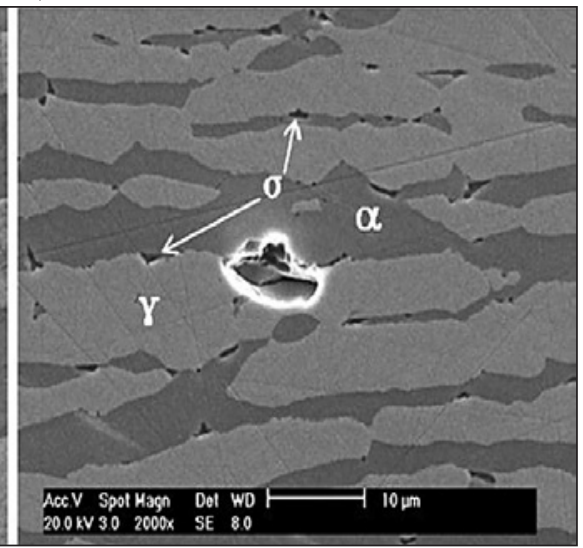

Fig. 5. SEM morphologies after corrosion attack (a) metastable pit formed on the solution annealed specimen and (b) metastable pit formed on the specimen aged for $10 \mathrm{~min}$ [54] 


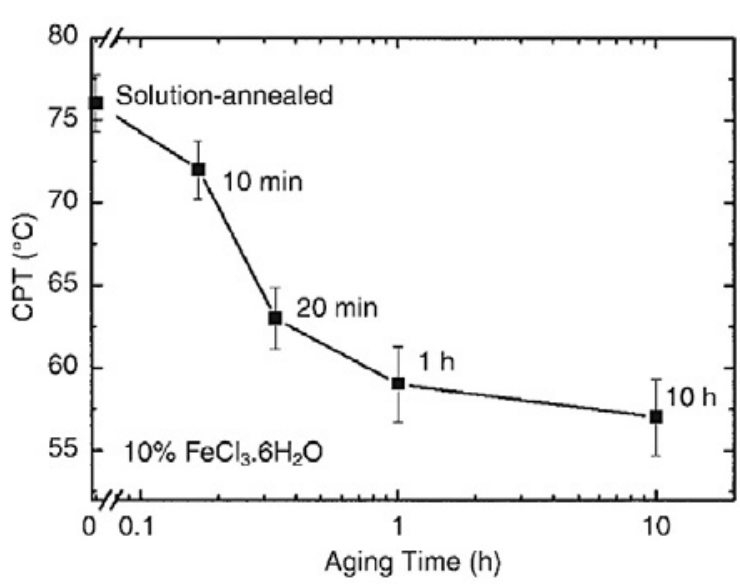

Fig. 6. Effect of aging time on $\mathrm{CPT}$ in $10 \% \mathrm{FeCl}_{3}-$ $6 \mathrm{H}_{2} \mathrm{O}$ solution at $850{ }^{\circ} \mathrm{C}[58]$

Fargas et al. [59] conducted potentio-dynamic polarization studies in a three electrodes cell. The platinum electrode was used as counter-electrode, specimen as working electrode and $\mathrm{Ag} / \mathrm{AgCl}$ as reference electrode. The testing was done at 875, 925 and $975^{\circ} \mathrm{C}$. They found out that pitting is caused due to secondary austenite phase at $875^{\circ} \mathrm{C}$. But at high annealing temperatures (i.e. $925-975^{\circ} \mathrm{C}$ ), high diffusion rate of $\mathrm{Cr}$ and Mo replenishes the once depleted zones and the number of sites prone to pitting are reduced. The variation of pitting potential at different aging temperatures is shown in Figue 7.

(a)

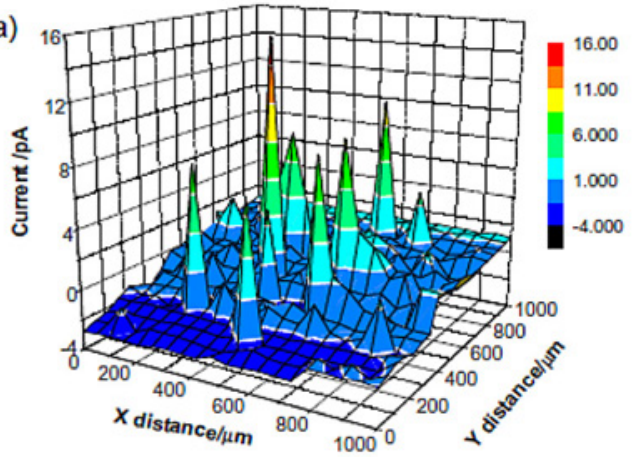

(b)

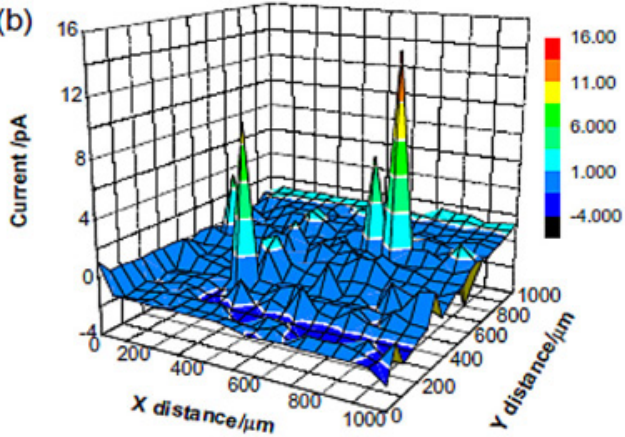

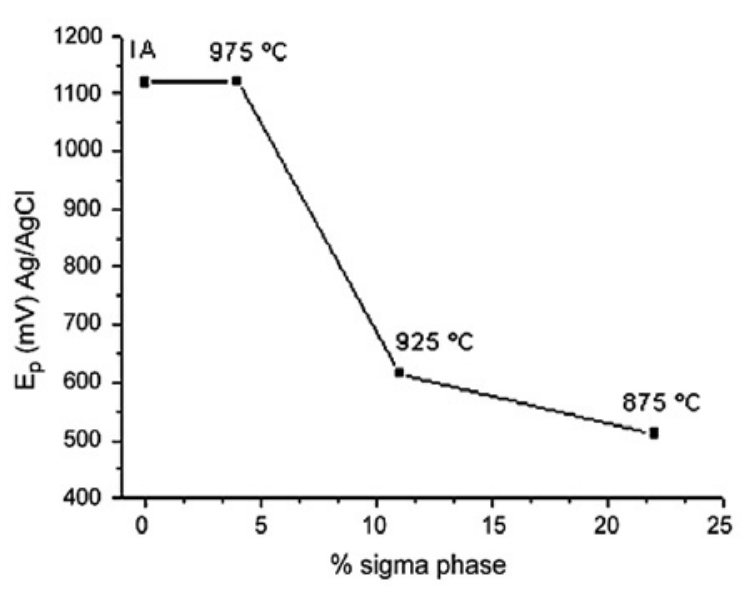

Fig. 7. Variation of pitting potential at different aging temperatures [59]

Luo, H. et al. [60] studied the effect of solution heat treatment at $1100{ }^{\circ} \mathrm{C}$ for 1 hour on the corrosion behaviour of DSS. The specimen were immersed in test solutions before any measurement. The authors concluded that alloying elements content in both phases changed with solution heat treatment. Also, the pitting sites were decreased in number after solution heat treatment. At the open circuit potential, more pitting sites are observed in original sample than solution treated sample as shown in Figure 8. In solution treated sample the pits are found to be of larger size than
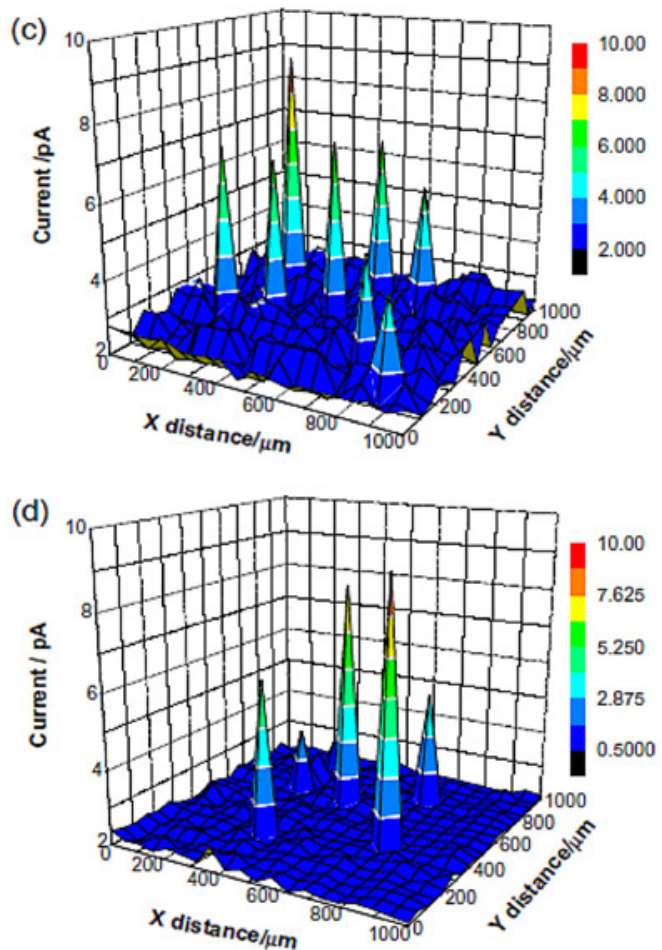

Fig. 8. Saturated Calomel Electrode Microscope (SCEM) images of 2205 duplex stainless steel surface after immersion in $\mathrm{NaCl}$ at the open circuit potential. (a) Original state (immediately); (b) after solution treatment (immediately); (c) original state (after $1 \mathrm{~h}$ immersion); (d) after solution treatment (after $1 \mathrm{~h}$ immersion) [60] 
the pits in original sample. This indicates pitting in solution treated sample will occur only at already available pits from original samples rather than forming new pits.

The pitting potential (Ep) is defined as the potential at which the anodic current density increased sharply with respect to the background passive current density. Ezuber et al. [61] analysed seawater pitting caused due to sigma precipitation. They made an interesting conclusion that at room temperature, DSS is immune to pitting corrosion even in the presence of sigma phase but at $50{ }^{\circ} \mathrm{C}$ seawater temperature, it is susceptible to pitting. This is because at high temperatures, cathodic reaction takes place on passive film which causes reduction in oxygen. This leads to formation of large number of corrosion cells.

Wilms et al. [62] studied the consequences of sigma phase precipitation on seawater corrosion of SDSS. They found that localized corrosion starts after 7 min of aging at $800{ }^{\circ} \mathrm{C}$ due to formation of Sigma and secondary austenite. The sensi-

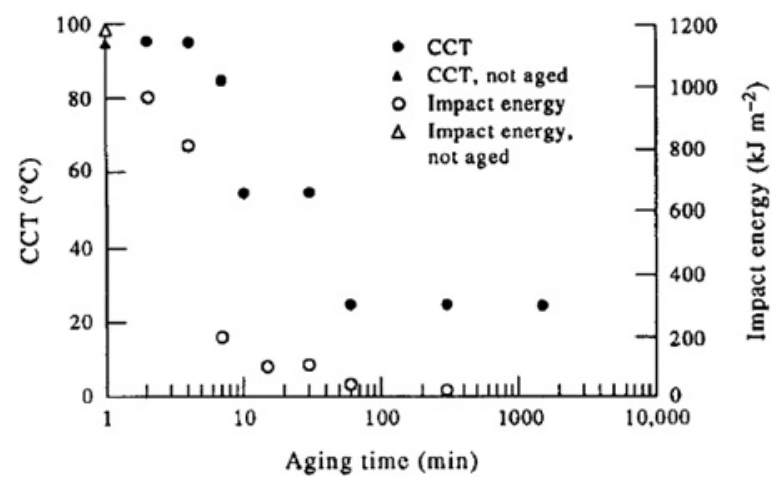

Fig. 9. Variation of Critical Crevice Temperature and impact toughness with aging time [62]

a)

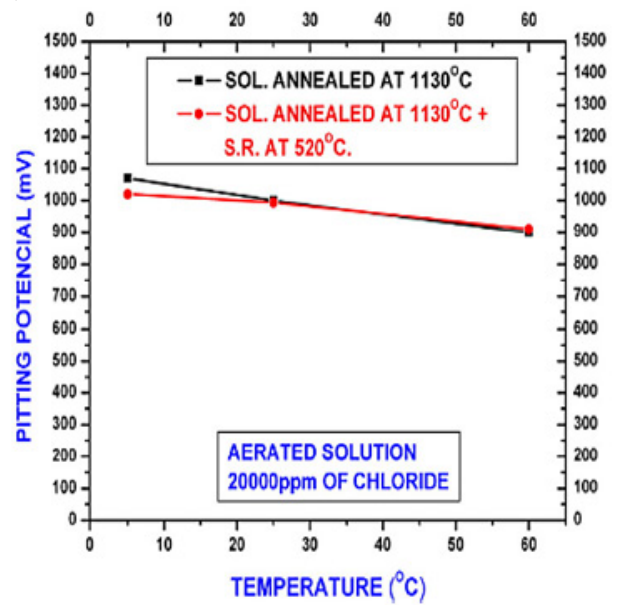

tivity comparison of pitting corrosion and toughness to sigma phase content is shown in Figure 9. This clearly indicates toughness is more sensitive to Sigma phase than corrosion as toughness is affected just after 2 min of aging, much before it affects the crevice corrosion resistance.

Martins et al. [45] studied corrosion behaviour of super duplex stainless steel castings. They concluded that pitting potential decreases with increase in work temperature. Hence in offshore industries where temperatures may go up to $60^{\circ} \mathrm{C}$, material becomes prone to pitting. They also pointed that stress relief treatment does not have any effect on pitting potential as shown in Figure 10.

For DSS, the breakdown / pitting potential is the potential at which anodic current density reaches a value of $100 \mu \mathrm{A} / \mathrm{cm}^{2}$ [63]. Ebrahimi et al. [64] evaluated CPT of DSS 2205 in $0.1 \mathrm{M}$ $\mathrm{NaCl}$ solution by various techniques. Through potentio-dynamic measurements, the authors found out that the transition from trans-passivity to pitting corrosion occurs in between 45 to $55{ }^{\circ} \mathrm{C}$. The breakdown potential for DSS was found to be $970 \mathrm{mV}$ at $55^{\circ} \mathrm{C}$. Hence the passivity domain decreased from $1200 \mathrm{mV}$ at $45^{\circ} \mathrm{C}$ to $700 \mathrm{mV}$ at $65^{\circ} \mathrm{C}$. Figure 11 shows variation of breakdown potential with work temperature for 20Cr-28Ni and DSS 2205 in $0.1 \mathrm{M} \mathrm{NaCl}$ solution.

Palmer [65] found the precipitation of chromium nitrides during spot welding of 2205 DSS. The precipitates were dark in appearance and formed due to saturation of $\mathrm{N}$ in ferrite grains during rapid cooling. These chromium nitrides cause depletion of $\mathrm{Cr}$ in ferrite grains making it prone to corrosion attack.

b)

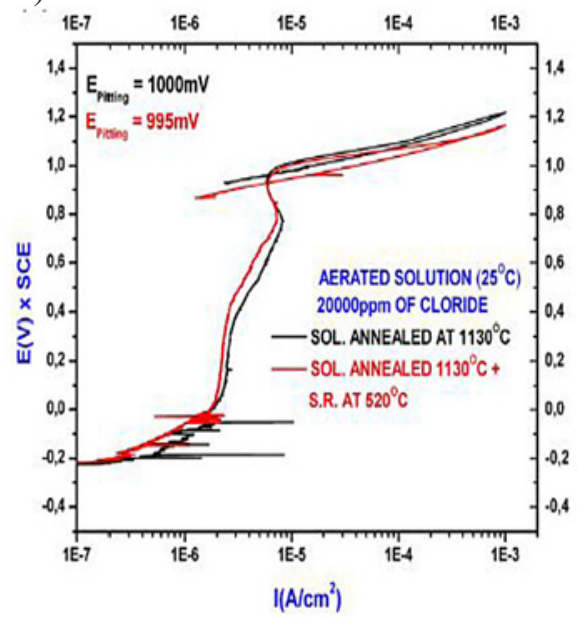

Fig. 10. Effect of stress relief treatment on pitting a) Variation of pitting potential with test temperature;

b) Anodic polarization curves for solution annealed and solution annealed + stress relieved [45] 


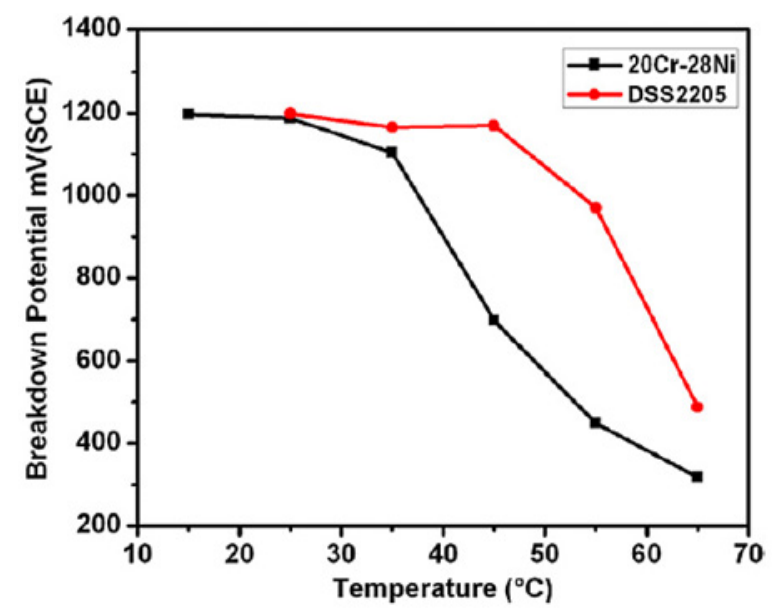

Fig. 11. Variation of breakdown potential with working temperature [64]

Ogawa and Koseki [66] performed GTAW on various grades of 22Cr3Mo DSSs by varying the amounts of nitrogen and nickel. They found that the nitrogen bearing specimen had inferior pitting resistance of ferrite phase than other samples due to precipitation of nitrides. They also concluded that decrease in grain size and cooling rate would decrease nitrides precipitation within ferrite.

Barnhouse and Lippold [67] studied dissimilar GTAW welding joints of carbon steels and DSS with both DSS and $625 \mathrm{Ni}$ alloy filler materials. In both welds, a significant amount of secondary austenite was found due to reheating of weld in subsequent passes of multi-pass welding. They reported a slight increase in hardness. There was evidence of increase in pitting corrosion resistance with high heat input because of slow cooling rates and formation of austenite instead of nitrides.

Yousefieh et al. [68] carried out GTAW of UNS S32760 which was followed by step annealing heat treatments at various temperatures ranging from 550 to $1000{ }^{\circ} \mathrm{C}$ for $15 \mathrm{~min}$. It was found that CPT for welded sample was $55^{\circ} \mathrm{C}$. After step annealing, the CPT values for all the specimen were increased. In between $550-750{ }^{\circ} \mathrm{C}$, CPT value decreased from $70{ }^{\circ} \mathrm{C}$ to $65^{\circ} \mathrm{C}$ due to precipitation of chromium nitrides. At high temperatures up to $900{ }^{\circ} \mathrm{C}$ it further decreased due to precipitation of sigma and secondary austenite phases. Again at the annealing temperatures above 900 ${ }^{\circ} \mathrm{C}$, the CPT values increased due to replenishment of ferrite phase. The variation of CPT with annealing temperatures is shown in Figure 12.

Shin et al. [69] investigated the pitting behavior of GTAW SDSS weldments with respect to

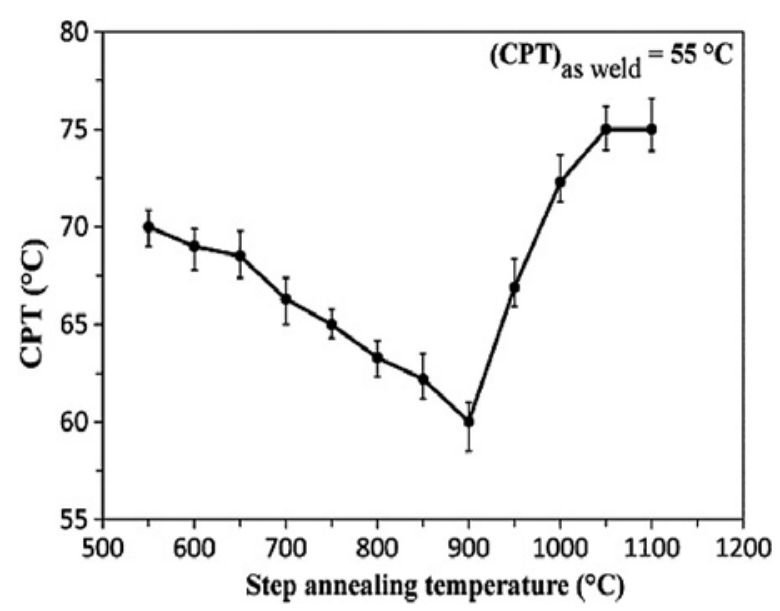

Fig. 12. CPT vs annealing temperatures of UNS S32760 weldments [68]

heat input. The results showed the pitting resistance was significantly reduced by the secondary austenite formation. The morphology of secondary austenite played an important role. The secondary austenite of acicular type was found to be more hazardous than polygonal type.

Cervo et al. [70] studied the effect of annealing heat treatment on UNS S32750 DSS welds. Two thick plates of $15 \mathrm{~mm}$ size were welded by submerged arc welding method. The pitting behavior of the weldments was studied. The authors found that PREN of welded zone was lower than that of base material. This was attributed to low contents of CR, Mo and $\mathrm{N}$ in ferrite caused by improper weld heat cycle [71]. The Post Weld Heat Treatments (PWHT) improved PREN values due to proper partitioning of elements in two phases. Later, they concluded that PWHT at 1100 ${ }^{\circ} \mathrm{C}$ gives the best outcome.

\section{Inter-Granular Corrosion (IGC)}

The oxide or hydroxide layers of several nanometres thickness formed on the surfaces of metals protects them from corrosive environment. Examples of such metals are $\mathrm{Fe}, \mathrm{Mo}, \mathrm{Cr}$, Ni and their alloys. Therefore DSS \& SDSS are protected by passive films. The integrity of passive films greatly depends upon $\mathrm{Cr}$, Mo and $\mathrm{N}$ contents in the material. When intermetallic phases are formed in DSS and SDSS, the adjacent grain boundaries are depleted in $\mathrm{Cr}$ and Mo content. These boundaries are then prone to corrosion attack. Hence $\mathrm{Cr} / \mathrm{Mo}$ depleted zones act as the anode (active dissolution) and the surrounding passive film acts as the cathode (passive dissolution). This behaviour is 
recorded on potentiostat which gives applied potential vs current density plot. This phenomenon is also known as Inter-granular Attack (IGA). Intergranular corrosion occurs when grain boundaries of the material are more prone to corrosion attack than grains.

The material's susceptibility to inter-granular corrosion is measured by Degree of Sensitization (DOS). The DOS is given by the $\left(I_{\mathrm{r}} / I_{\mathrm{a}}\right) \times 100$, where $I_{\mathrm{a}}$ and $I_{\mathrm{r}}$ are the peak current density in activation (forward scan) and the maximum current density in reactivation (reverse scan) respectively. The electrochemical potentio-kinetic reactivation test (EPR test) was established to measure DOS for nickel alloys and stainless steels [72]. There are two types of EPR tests; Single Loop (SL) EPR test and Double Loop (DL) EPR test.

In a single loop EPR test, polarization curve is with a potential scan from the passive range to open circuit potential (OCP) i.e. reverse scan. In DL-EPR test, polarization curve consists of forward scan and a reverse scan starting at active OCP. DL-EPR test is most commonly preferred because of its simplicity and ease in sample preparation [73]. The curve obtained in this test is shown in Figure 13.

Amadou et al. [74] employed Double LoopEPR test to check IGC susceptibility of DSS. They concluded that the test is powerful technique to investigate intergranular corrosion caused by various secondary phases like $\mathrm{Cr}_{23} \mathrm{C}_{6}$ carbides, chi and sigma phases. These phases cause depletion in $\mathrm{Cr}$ content making Cr-depleted zones prone to IGC.

Ortiz et al. [75] carried out DL-EPR tests on UNS S31803 DSS specimen aged at $700{ }^{\circ} \mathrm{C}$ for time 1 min to 240 hours. The DL-EPR test was

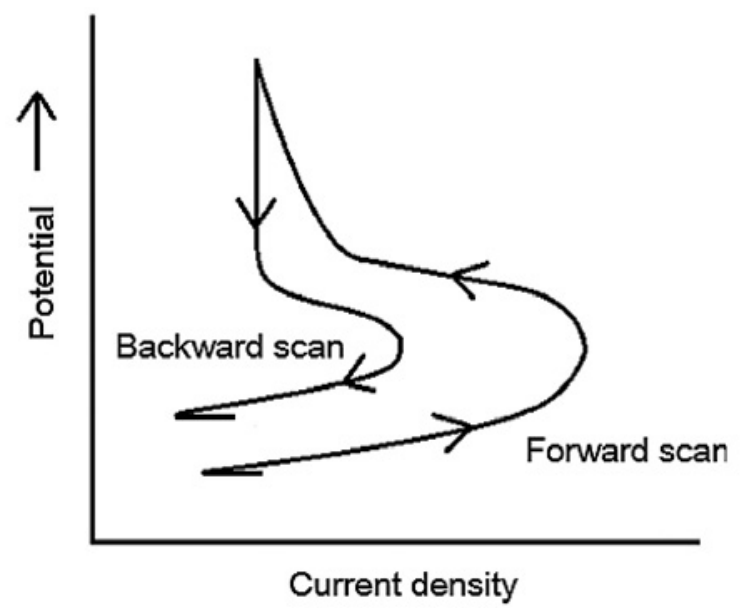

Fig. 13. Double Loop electrochemical potentio-kinetic reactivation test [73] conducted in $2 \mathrm{M} \mathrm{H}_{2} \mathrm{SO}_{4}+0.01 \mathrm{M} \mathrm{KSCN}+0.5$ $\mathrm{M} \mathrm{NaCl}$ with scan rate of $1 \mathrm{mV} / \mathrm{s}$. The as received specimen and aged specimens with aging time less than 1 hour exhibited very small DOS values which indicates absence of inter-granular corrosion. On further aging, DOS value started to increase to imply that precipitation of sigma phase caused inter-granular attack on DSS. By increasing aging time upto 240 hours, the DOS values increased nearly ten thousand folds as shown in Table 3.

Different authors investigated optimal combinations of electrolytes, electrolyte temperatures and scan rates [76 - 78] in DL-EPR test for different grades of DSS, which is given in Table 4.

Lopez et al. [79] conducted study of impact of sigma phase on corrosion properties of two different DSS. These two materials namely D1 and D2 varied in chemical composition. The aging treatments were carried out for $1 \mathrm{hr}$ to $10 \mathrm{hr}$ at $675{ }^{\circ} \mathrm{C}$ and $4 \mathrm{hr}$ at $900{ }^{\circ} \mathrm{C}$ to promote precipitation of secondary phases. The results showed harmful effects of sigma phase on intergranular corrosion. The steel D2 is more corrosion resistant than steel D1 for all low temperature heat treatments except for high temperature heat treatment at $900{ }^{\circ} \mathrm{C}$ for $4 \mathrm{hr}$. As nitrogen content was higher in steel D2 than that in steel D1, it retarded the formation of secondary phases. During heat treatment at high temperature, large amount of ferrite in steel D2 was dissolved into sigma phase hence, it showed less corrosion resistance than steel D1.

Table 3. Degree of sensitization at various aging times at $700{ }^{\circ} \mathrm{C}[75]$

\begin{tabular}{|c|c|}
\hline Specimen & DOS (Ir/la) (\%) \\
\hline As received & $9.74 \times 10^{-3}$ \\
\hline 1 min & $2.09 \times 10^{-2}$ \\
\hline $30 \mathrm{~min}$ & $2.34 \times 10^{-2}$ \\
\hline 1 hour & $7.66 \times 10^{-2}$ \\
\hline 6 hours & 17.40 \\
\hline 48 hours & 64.91 \\
\hline 240 hours & 88.83 \\
\hline
\end{tabular}

Table 4. Optimal combinations of experimental setups for different DSS grades [76-78]

\begin{tabular}{|c|c|c|}
\hline Grade & Electrolyte & Scan rate \\
\hline UNS S31803 & $2 \mathrm{M} \mathrm{H}_{2} \mathrm{SO}_{4}+1.0 \mathrm{M} \mathrm{HCl}$ at $30{ }^{\circ} \mathrm{C}$ & $1.66 \mathrm{mV} / \mathrm{s}$ \\
\hline UNS S32750 & $2 \mathrm{M} \mathrm{H}_{2} \mathrm{SO}_{4}+1.5 \mathrm{M} \mathrm{HCl}$ at $30{ }^{\circ} \mathrm{C}$ & $1.5 \mathrm{mV} / \mathrm{s}$ \\
\hline UNS S32101 & $33 \% \mathrm{H}_{2} \mathrm{SO}_{4}+0.1 \% \mathrm{HCl}$ at $20^{\circ} \mathrm{C}$ & $2.5 \mathrm{mV} / \mathrm{s}$ \\
\hline
\end{tabular}


Other phases like alpha-prime ( $\left.\alpha^{\prime}\right)$ phase also affect inter-granular corrosion in DSS. Lo et al. [80] studied effect of prolonged aging on 7MoPlus DSS at lower temperatures of 300, 400 and $500{ }^{\circ} \mathrm{C}$. At 300 and $400{ }^{\circ} \mathrm{C}$, DOS was low even after aging for $15000 \mathrm{hr}$. But at $500{ }^{\circ} \mathrm{C}$, due to spinodal decomposition, Cr-depleted ferrite was created next to Cr-rich ferrite. This Cr-depleted zone is prone to IGC. Figure 14 shows the variation of DOS with annealing time at different temperatures.

\section{Stress Corrosion Cracking (SCC)}

When material is subjected to tensile stress in corrosive environment, passive film breaks easily and cracks are formed which cause material to fail in brittle way. These cracks can propagate in inter-granular or trans-granular manner across the grains. This concept is known as Stress Corrosion Cracking (SCC).

DSS are more passive to SCC than austenitic stainless steels. Slow Strain Rate Test (SSRT) is

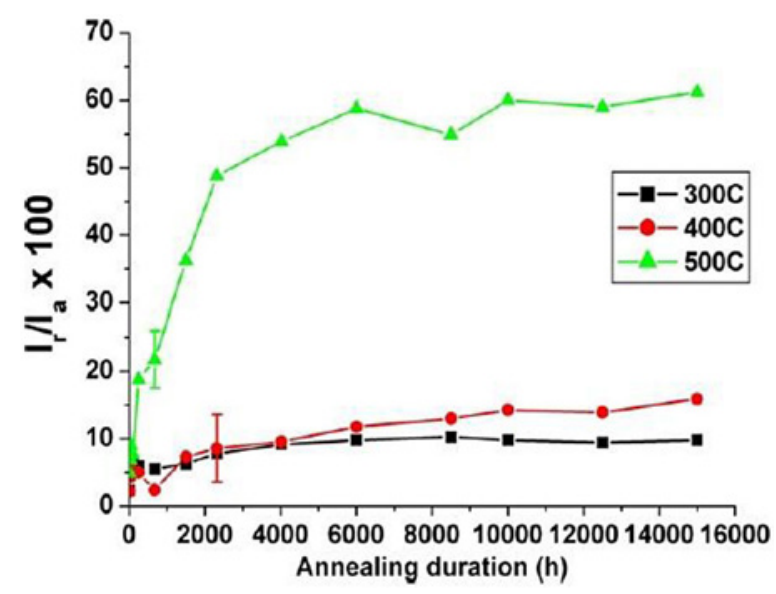

Fig. 14. DOS vs annealing time at various temperatures [80]

a)

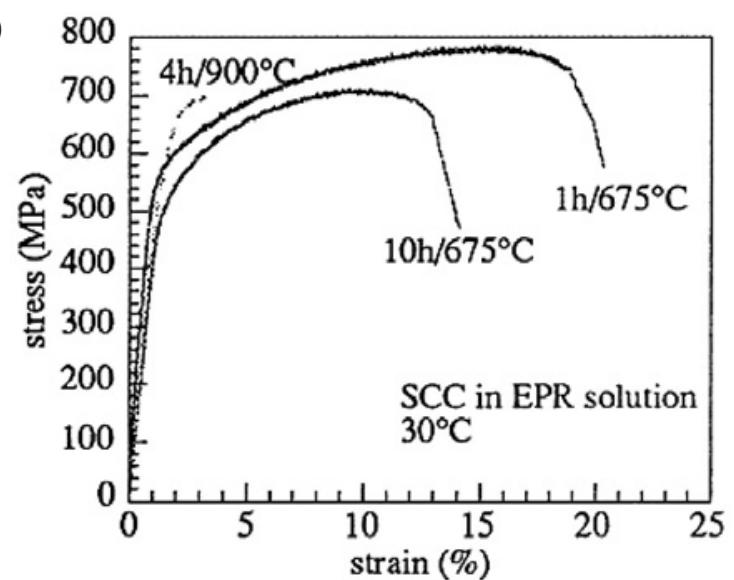

the most commonly used technique to test the susceptibility of DSSs to SCC. The applied strain rates vary in the range of $10^{-6}$ to $10^{-7} / \mathrm{s}$.

The $\alpha$-phase and $\gamma$-phase are vulnerable to SCC in hot chloride and hot alkaline solutions respectively. The crack initiation takes place at $\gamma$-phase and at the interfaces due to microstructural anisotropy effects.

Lopez et al. [79] investigated the detrimental effect of sigma phase on the resistance to SCC. The SSRT was conducted on the specimens aged for $1-10 \mathrm{hr}$ at $675{ }^{\circ} \mathrm{C}$ and $4 \mathrm{hr}$ at $900{ }^{\circ} \mathrm{C}$. The specimens were tested in different corrosive media such as EPR solution at $30^{\circ} \mathrm{C}$ and $\mathrm{MgCl}_{2}$ solution at $117{ }^{\circ} \mathrm{C}$. The specimen aged for $4 \mathrm{hr}$ at $900{ }^{\circ} \mathrm{C}$ was found to be more prone to SCC as shown in Fig. 15.

Tsai and Chen [81] tested annealed DSS 2205 at a strain rate of $4.6 \times 10^{-6} / \mathrm{s}$. They found that material is safe to SCC at open circuit potentials in $26 \% \mathrm{NaCl}$ solution but prone to SCC at high anodic potentials. The material was found to retain its ductility up to a potential of $-160 \mathrm{mV}$ at 90 ${ }^{\circ} \mathrm{C}$. There was loss in ductility at anodic potential higher than - $160 \mathrm{mV}$ as shown in Fig. 16.

Despite of very good mechanical properties and corrosion resistance, DSS are susceptible to hydrogen embrittlement [82]. The heat affected zones in weldments are prone to hydrogen embrittlement. It is well known that weldments of pipes in oil and gas industries suffer failures due to hydrogen induced cracking and cathodic protection [83].

El-Yazgi et al. [82] studied the SCC behaviour of DSS and SDSS in various sour solutions which are saturated with hydrogen sulphide- $\mathrm{H}_{2} \mathrm{~S}$ at temperatures of $2-95^{\circ} \mathrm{C}$. They found that there is a loss in ductility of DSS but SDSS retained its

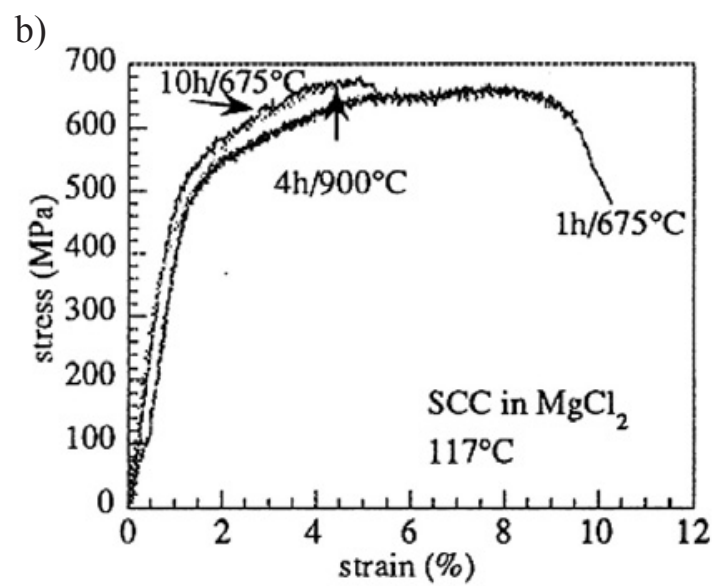

Fig. 15. SSRT for aged specimen a) In EPR solution at $30{ }^{\circ} \mathrm{C} \mathrm{b}$ ) $\mathrm{In} \mathrm{MgCl}_{2}$ solution at $117{ }^{\circ} \mathrm{C}$ [79] 


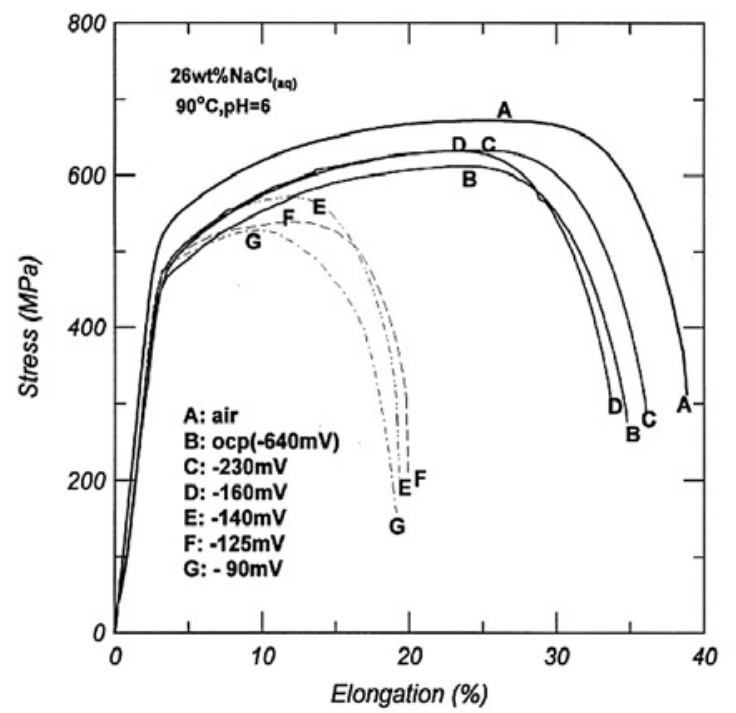

Fig. 16. Effect of applied potential on SCC resistance of DSS [81]

ductility in SSRT. The loss in ductility was because of absorption of hydrogen at the surfaces of the material. Due to higher content of alloying elements, SDSS material formed stable passive film even at higher temperatures.

Young et al. [84] studied hydrogen induced cracking of DSS through notched tensile tests and fracture properties. All the specimen were found to be susceptible to hydrogen embrittlement. This was confirmed by ductile fracture in air and quasi-cleavage fracture in $\mathrm{H}_{2}$. The authors also reported that ferrite is more susceptible to crack propagation than austenite. Figure 17. Shows results of Notched tensile tests in air and hydrogen environments. It was clear that in hydrogen environments, the material failed at lower stress value than in air.

Olden et al. [85] reported that hydrogen content of $40 \mathrm{ppm}$ at the surface and $1 \mathrm{ppm}$ at bulk

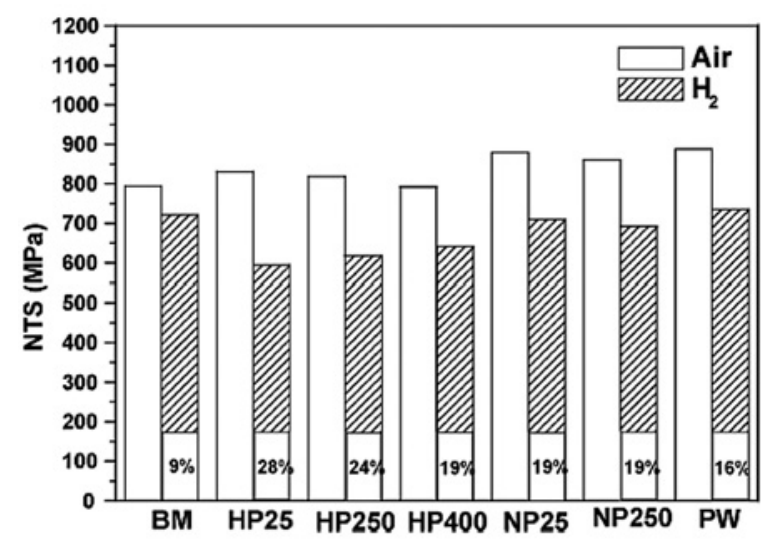

Fig. 17. Notched tensile tests in air and hydrogen environments [84] surface will initiate crack on the surface. Chou and Tsai [86] studied the effect of grain size in hydrogen induced cracking of DSS in $26 \% \mathrm{NaCl}$. It was found that the resistance to HIC was decreased with grain size coarsening.

Shinozaki et al. [87] found the cracking probability was increased significantly in GTAW welds when ferrite content exceeded 50\%. They also concluded that the increase in nitrogen content increased cracking sensitivity due to precipitation of $\mathrm{Cr}_{2} \mathrm{~N}$ in ferrite, which acts as initiation site for crack formation.

\section{EFFECT ON MECHANICAL PROPERTIES}

\section{Toughness}

Toughness is severely affected by formation of intermetallic phases and compounds [16, 18]. As metallic binding is weak in case of intermetallic phases, it causes bad-deformability of phases, ultimately deteriorating impact toughness of DSS [41]

In all studies it is found that even a small volume fraction of Sigma $(\sigma)$ phase causes drastic reduction in toughness value.

Pohl et al. [41] explained that at lower temperature Sigma $(\sigma)$ phase morphology shows a net like structure which causes cracks to propagate over long distances. This results in ferrite phase to cleave and ductile fracture in austenitic phase. At higher temperature bulk Sigma $(\sigma)$ phase is surrounded by bigger ferrite and austenite matrix. Hence, ferrite phase shows more ductile fracture as shown in Figures 18 and 19.

Badji et al. [88] studied effect of Sigma $(\sigma)$ phase in Gas Tungsten Arc Welding of DSS. They found that at annealing temperature 850 ${ }^{\circ} \mathrm{C}$, the least value of toughness is occurred. But when annealing temperature is above $1100^{\circ} \mathrm{C}$, the toughness value is increased because of increase in ferrite content.

Fargas et al. [59] conducted a study of effect intermediate annealing treatment on hot rolled steel. They concluded that in material behaves anisotropically with every mechanical property and toughness is the most sensitive to intermetallic phase formation. They also concluded that in transverse direction toughness is more than that of in longitudinal direction. This is because in transverse direction, crack has to propagate through large number of phase boundaries and in longitudinal direction crack propagation along duplex phases is easier as shown in Figure 20. 


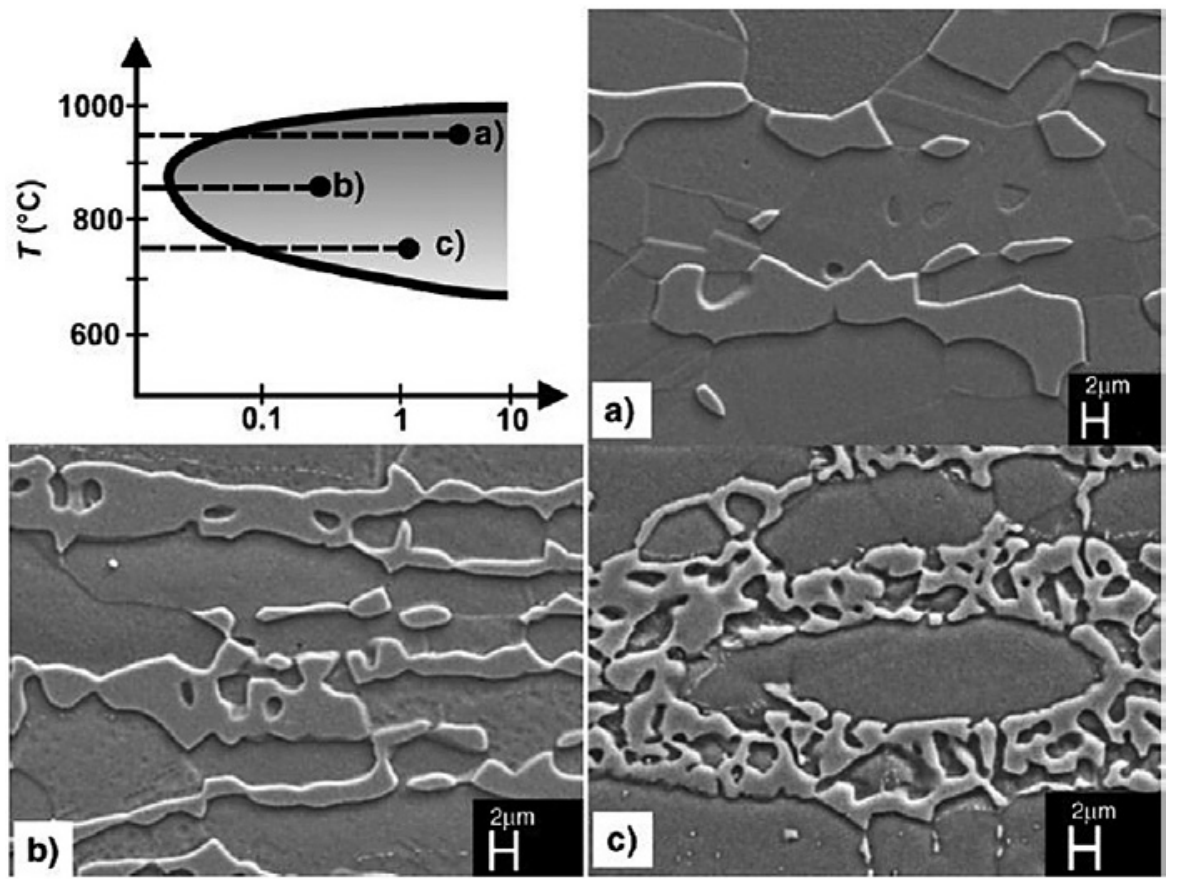

Fig. 18. Sigma phase morphology of at various aging temperatures a) $950{ }^{\circ} \mathrm{C}$, b) $850{ }^{\circ} \mathrm{C}$, c) $750{ }^{\circ} \mathrm{C}[41]$

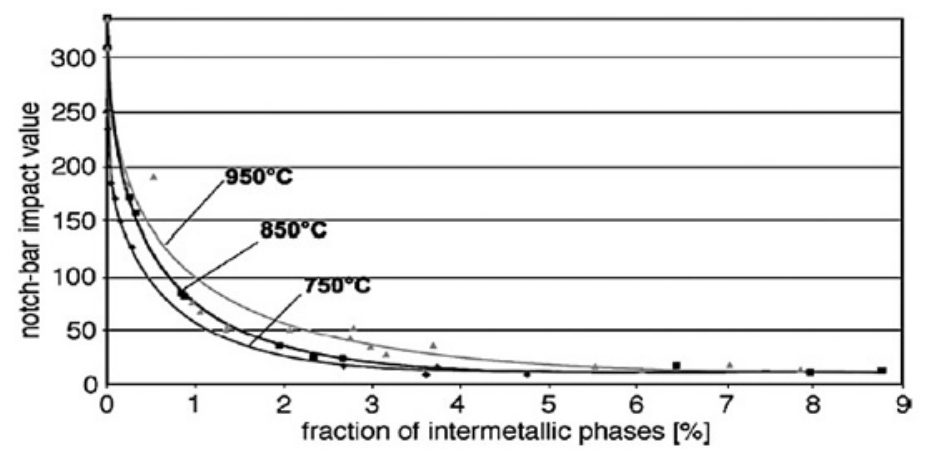

Fig. 19. Impact toughness vs fraction of intermetallic phases [41]

Topolska et al. [89] studied the toughness behaviour of Duplex Stainless Steels and Super duplex stainless steels. In their study they concluded DSS is less sensitive to embrittlement than Super DSS. The results are represented in Figure 21. At lower aging temperatures, DSS retains its toughness value. But in case of SDSS even at lower aging temperatures and lower aging times i.e. low Sigma phase content, material loses its impact energy absorbing capacity. The authors also claimed that the minimum allowable Sigma phase content in DSS and SDSS is 14\% and $8 \%$ respectively. These values correspond to critical impact energy value of $27 \mathrm{~J}$ in Industrial DSS applications.

Similar observations were made to evaluate minimum allowable sigma phase content in DSS pipe fittings in subsea applications [90]. The authors claimed that up to $5 \%$ sigma phase content is allowable. Above this level material will surely fail due to fracture. Besides $\sigma$-phase, other phases like R-phase and $475{ }^{\circ} \mathrm{C}$ embrittlement affect the impact toughness of the DSS $[50,51,53]$.

Sahu [53] investigated the effect of aging at $475^{\circ} \mathrm{C}$ on impact energy on DSS 1.4462 . He observed deterioration of impact toughness up to $8 \mathrm{~J}$ after $100 \mathrm{~h}$ of aging at this temperature as shown in Figure 22. On further aging, the impact toughness was plateaued at this value, which indicates there no further reduction in toughness values.

Cui et al. [50] studied the deterioration of impact toughness due to formation of R-phase in DSS with high nitrogen content. The formation of R-phase took place after aging at $500{ }^{\circ} \mathrm{C}$. The high nitrogen content retards formation of $\sigma$-phase in DSSs. It can be seen from Figure 23 that the R-phase was found to be dominant in 
a)

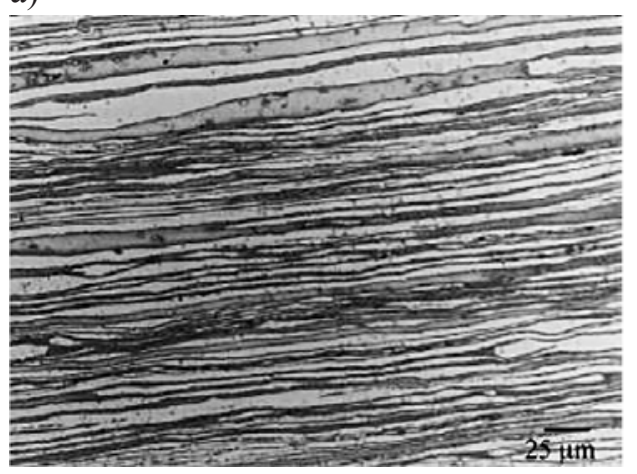

b)

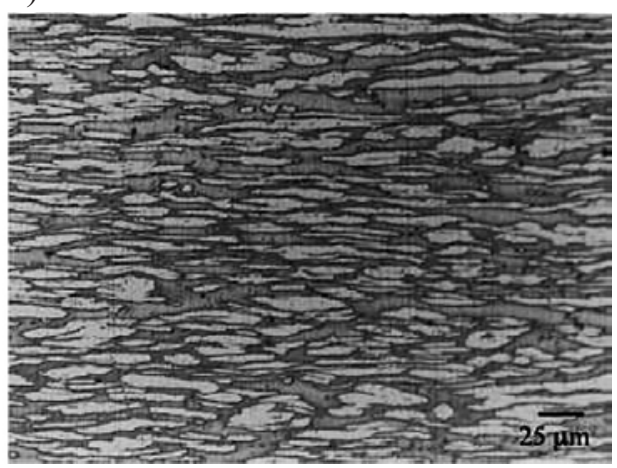

Fig. 20. Grain orientation in rolling in a) Longitudinal and b) Transverse direction [59]

a)

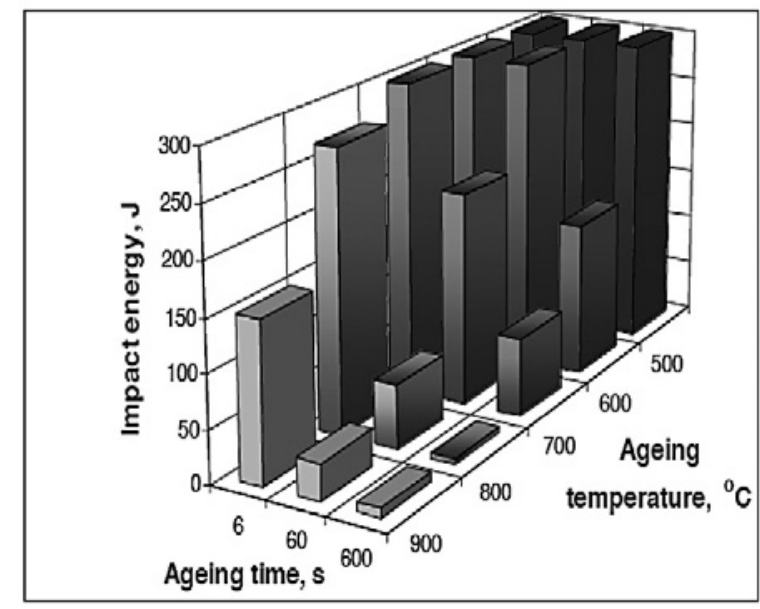

b)

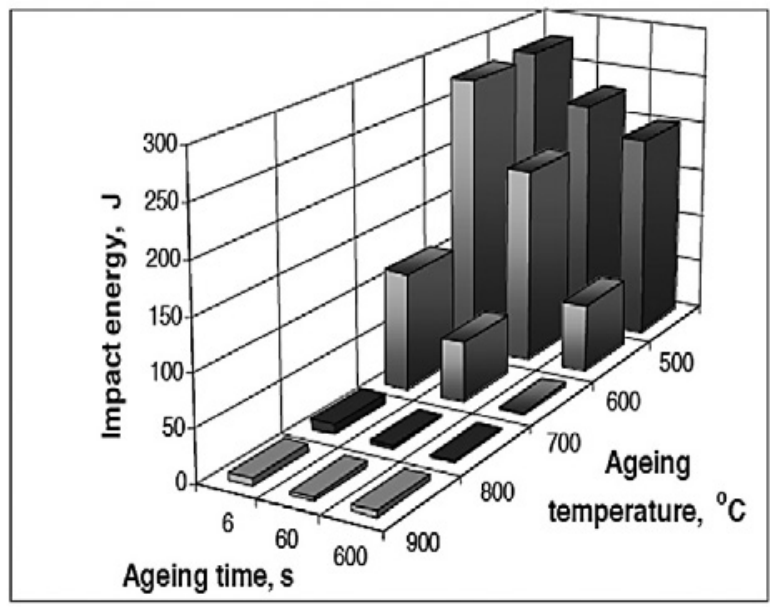

Fig. 21. Impact toughness vs aging temperature vs aging time for a) DSS b) SDSS [89]

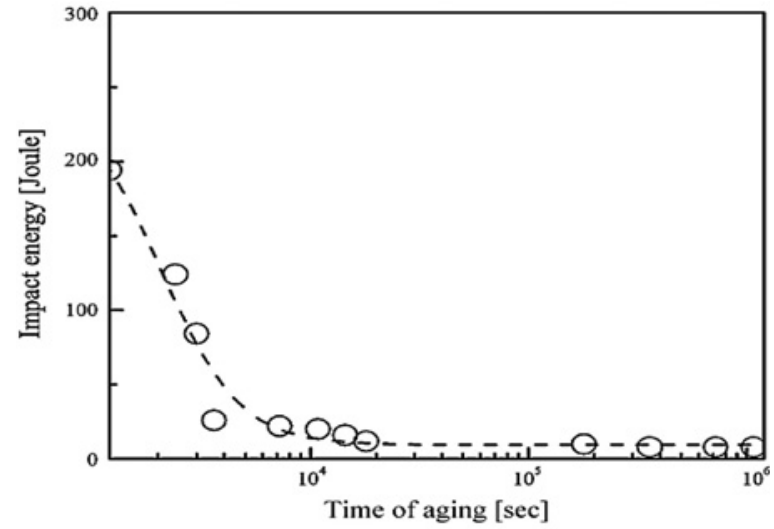

Fig. 22. Impact energy vs time of aging at $475^{\circ} \mathrm{C}[53]$

degradation of impact energy after aging time of $6 \mathrm{hr}$ and $10 \mathrm{hr}$ for $25 \mathrm{Cr}-7 \mathrm{Ni}-\mathrm{N}$ and $25 \mathrm{Cr}-7 \mathrm{Ni}-$ Mo respectively.

Hwang et al. [51] studied the effect of Rphase on impact toughness of Super DSS. They found that at initial stage of aging at $600{ }^{\circ} \mathrm{C}, \mathrm{R}$ phase was formed and later it was transformed to sigma phase. The reduction in toughness with Rphase was found to be drastic.

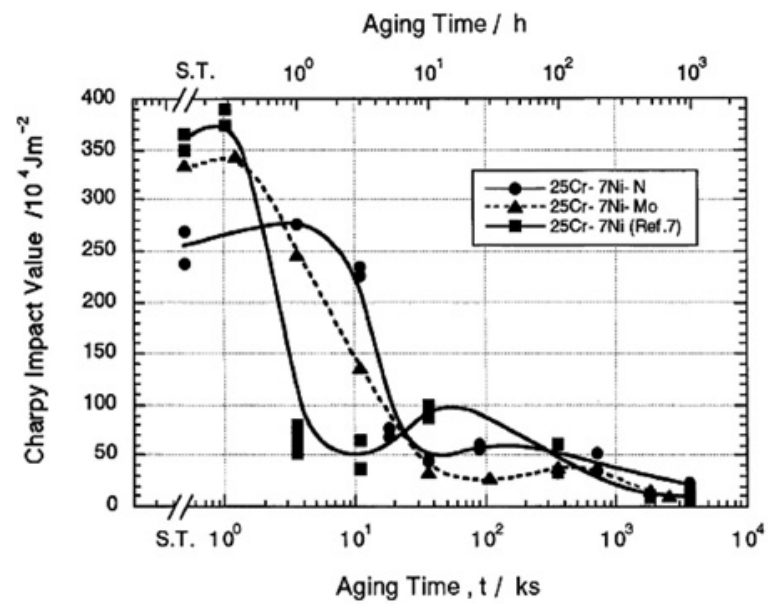

Fig. 23. Charpy impact value vs aging time at $500^{\circ} \mathrm{C}$ [50]

\section{Hardness}

The intermetallic phases occur in duplex stainless steel are hard and fragile. With increase in their content, they consume almost all ferrite available. Karlsson et al. [91] reported embrittlement of material due to increase in volume fraction of intermetallic phases and decrease in ferrite content. 
Similar studies were done by Martins et al. [92] with Super DSS. They concluded that with increase in Sigma $(\sigma)$ phase content hardness values increased as shown in Figure 24. From the figure it is clearly visible that hardness increases in parabolic manner with increase in sigma phase content. But a significant increase in hardness is observed only at higher sigma phase content.

Chen et al. [83] studied the effect of different aging temperatures between $650-975{ }^{\circ} \mathrm{C}$ and aging times on microstructure and mechanical properties of DSS. They found out that hardness increases with increase in aging time for all temperatures as shown in Figure 25. But hardness shows sharp increase only after longer aging times of $30 \mathrm{~min}$ whereas in case of toughness only 5 min aging is enough to make a drastic reduction. This indicates hardness is not a measure of low volume fraction of Sigma phase. Similar conclusions were made by Karlsson et al. [91], where they concluded toughness is more sensitive than hardness to effects of low volume percentage of intermetallic phases.
Cui et al. [50] studied hardness behaviour with aging time. They found out that, with increase in aging time hardness increases gradually after 14 hrs and 8.3 hrs for both 25Cr-7Ni-N and 25Cr7Ni duplex stainless steels as shown in Figure 26. The significant increase in Vicker hardness was found to be at aging time of $1400 \mathrm{hrs}$ and $100 \mathrm{hrs}$ for $25 \mathrm{Cr}-7 \mathrm{Ni}-\mathrm{N}$ and $25 \mathrm{Cr}-7 \mathrm{Ni}$ respectively. This corresponds to with increase in aging time, hard sigma phase content increases which increases hardness of the material. After 2700 hrs aging time, hardness starts decrease for $25 \mathrm{Cr}-7 \mathrm{Ni}-\mathrm{N}$ DSS because its high Nitrogen content retards the formation of Sigma phase.

Rovere et al. [86] studied effect of prolonged aging (up to $7000 \mathrm{hr}$ ) at $300{ }^{\circ} \mathrm{C}$ and $400{ }^{\circ} \mathrm{C}$ on 2205 DSS as shown in Figure 27. At $300^{\circ} \mathrm{C}$ aging, hardness values did not vary significantly. But at $400{ }^{\circ} \mathrm{C}$, hardness of ferrite was increased. But austenite remained unaffected even after aging. The spinodal decomposition of ferrite caused embrittlement of phase. After $5000 \mathrm{hr}$ aging at $400{ }^{\circ} \mathrm{C}$, hardness was found to be de-

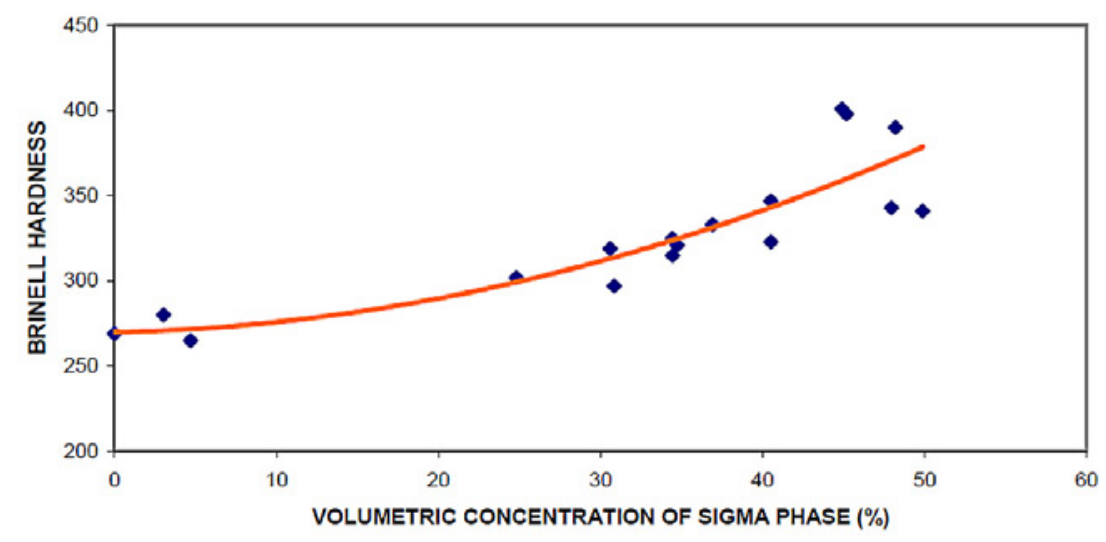

Fig. 24. Brinell hardness vs sigma phase volume fraction [92]

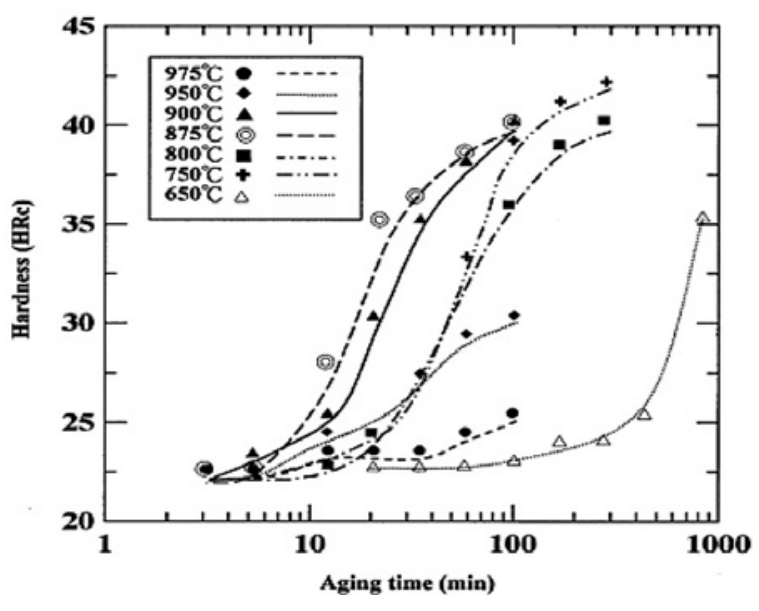

Fig. 25. Hardness variation with aging time at different aging temperatures [83]

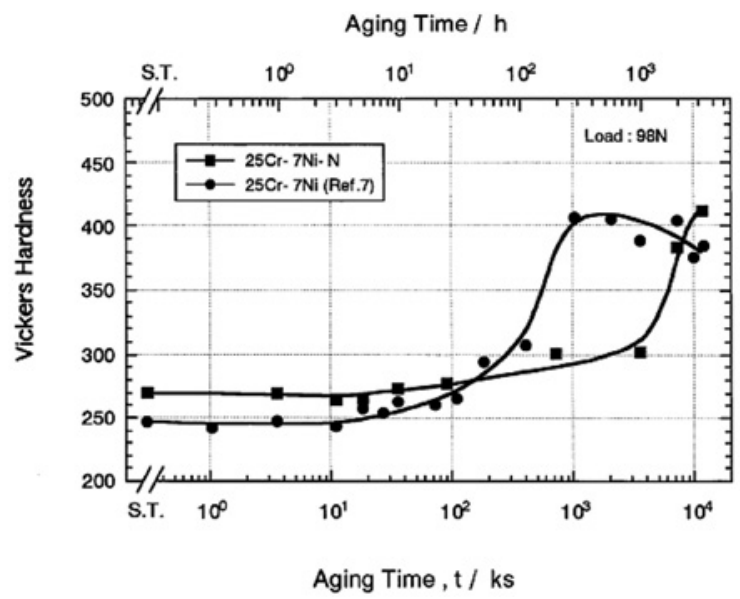

Fig. 26. Vickers hardness vs aging time at $873 \mathrm{~K}$ for alloys $25 \mathrm{Cr}-7 \mathrm{Ni}$ and $25 \mathrm{Cr}-7 \mathrm{Ni}-\mathrm{N}$ [50] 
a)

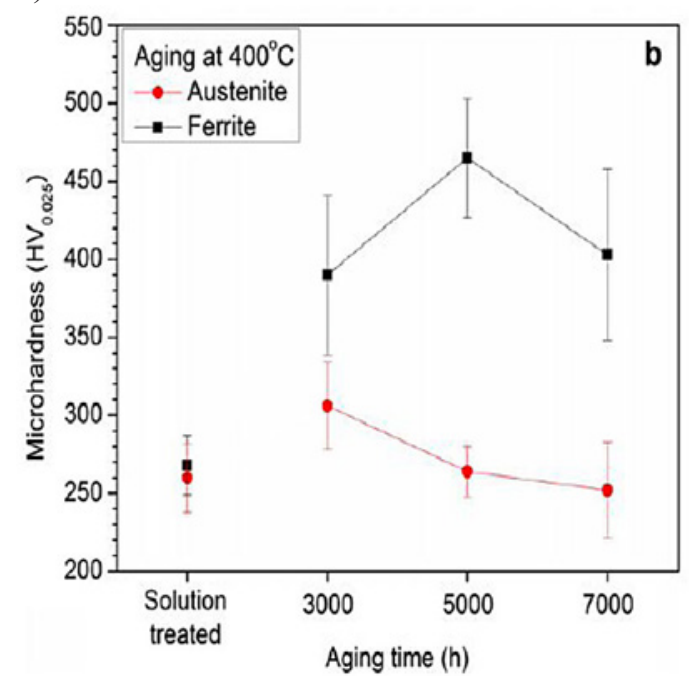

b)

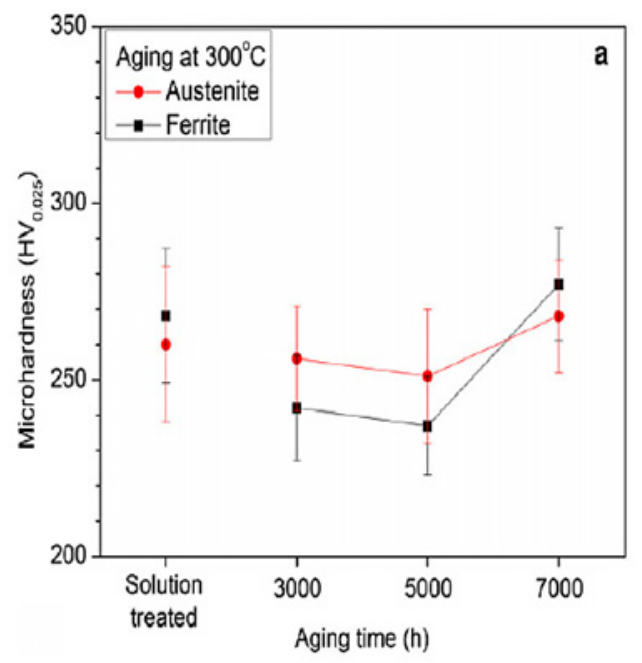

Fig. 27. Hardness variation with aging time at a) $400{ }^{\circ} \mathrm{C}$ and b) $300^{\circ} \mathrm{C}$ [86]

creased due to coarsening of phases or loss of coherent nature of precipitates.

\section{Tensile strength}

Pohl et al. [41] concluded that the Sigma $(\sigma)$ phase formation causes increase in tensile and yield strength between temperatures $750-850{ }^{\circ} \mathrm{C}$. This is because of net like structure in obtained at low temperatures as shown in Figure 28. At 850 ${ }^{\circ} \mathrm{C}$, internal brittle micro-cracking of Sigma $(\sigma)$ phase causes reduction in strength beyond general material yield level known as 'low stress failures'. But at higher annealing temperatures tensile strength hardly shows any change with increase in Sigma $(\sigma)$ phase volume fraction.

Li et al. [93] studied the influence of Sigma $(\sigma)$ phase formation on tensile properties of SDSS. They concluded that at $600{ }^{\circ} \mathrm{C}$, with increase in Sigma $(\sigma)$ phase content from 0 to $26 \%$, tensile strength increases. But at higher tempera-

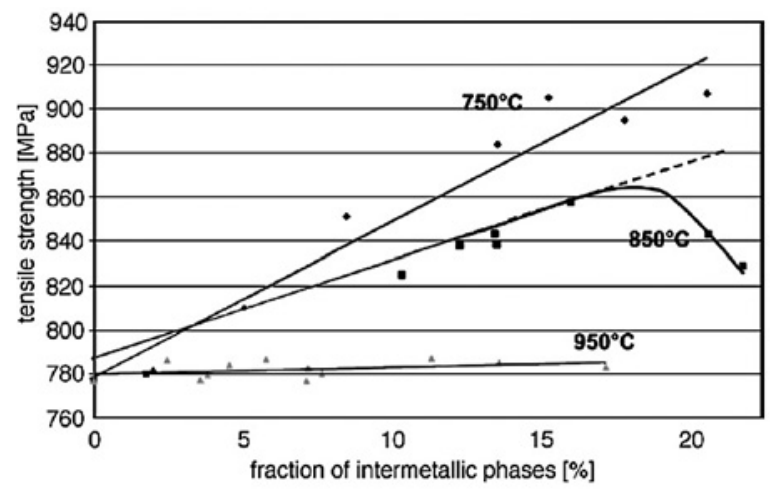

Fig. 28. Tensile strength variation with $\%$ intermetallic phases [41] tures $900{ }^{\circ} \mathrm{C}$, the effect of Sigma $(\sigma)$ phase is negligible. The results are represented in Figure 29.

\section{CONCLUSIONS}

The intermetallic phases cause changes in mechanical and corrosion properties of DSS and SDSS. Intermetallic phases occur in particular temperature range of 500 to $1000{ }^{\circ} \mathrm{C}$. These intermetallic phases formation is more severe in welding and it becomes challenge to the welding Industries.

The chemical composition, aging temperature play an important role in intermetallic phase precipitations. Toughness is drastically reduced even with small volume fraction of intermetallic phases. Intermetallic phases are hard and brittle

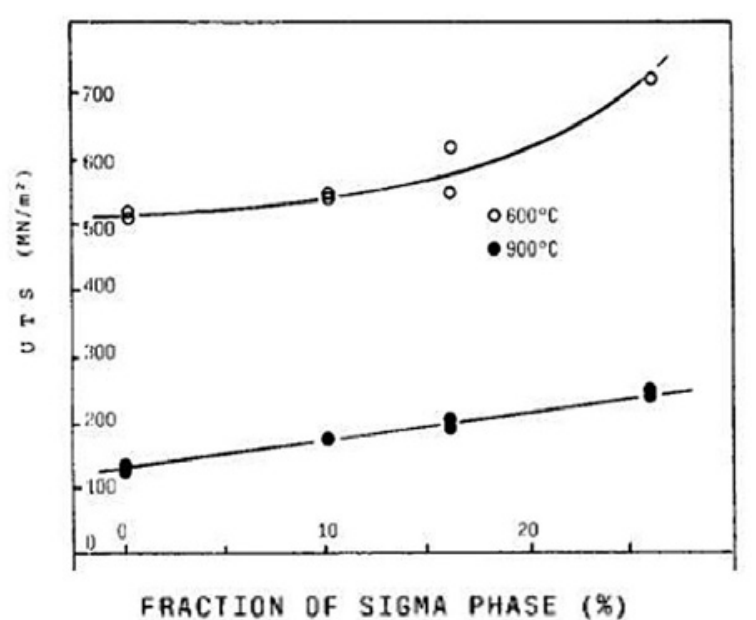

Fig. 29. UTS vs fraction of sigma phase at different aging temperatures [93] 
which cause embrittlement of the material. Corrosion resistance is lowered by the presence of intermetallic phases. Out of all intermetallic phases, the sigma phase is the most hazardous one.

In order to achieve better corrosion and mechanical properties on DSS and SDSS materials, it is important to control these phases formation. With appropriate chemical compositions and heating and cooling rates, we can avoid these detrimental phase formation with improved mechanical and corrosion properties.

\section{REFERENCES}

1. Olsson J., Snis M. Duplex - A new generation of stainless steels for desalination plants. Desalination 2007, 205, 104-113.

2. Chen T., Weng K., Yang J. The effect of high-temperature exposure on the microstructural stability and toughness property in a 2205 duplex stainless steel. Mater. Sci. Eng. A 2002, 338, 259-270.

3. M M.A., Shrikrishna K.A., Sathiya P., Goel S. The impact of heat input on the strength, toughness, microhardness, microstructure and corrosion aspects of friction welded duplex stainless steel joints. J. Manuf. Process. 2015, 18, 92-106.

4. Sato Y.S., Nelson T.W., Sterling C.J., Steel R.J., Pettersson C.-O. Microstructure and mechanical properties of friction stir welded SAF 2507 super duplex stainless steel. Mater. Sci. Eng. A 2005, 397, 376-384.

5. Perren R.A., Suter T., Solenthaler C., Gullo G. Corrosion resistance of super duplex stainless steels in chloride ion containing environments: investigations by means of a new microelectrochemical method II. Influence of Precipitates 43, 2001, 727-745.

6. Fargas G, Mestra A., Mateo A. Effect of sigma phase on the wear behavior of a super duplex stainless steel. Wear 2013, 303, 584-590.

7. Chen T., Weng K., Yang J. The effect of high-temperature exposure on the microstructural stability and toughness property in a 2205 duplex stainless steel. Mater. Sci. Eng. A 2002, 338, 259-270.

8. Calonne V., Berdin C., Saint-Germain B., JayetGendrot S. Damage and dynamic strain aging in a thermal aged cast duplex stainless steel. J. Nucl. Mater. 2004, 327, 202-210.

9. Baddoo N.R. Stainless steel in construction: A review of research, applications, challenges and opportunities. J. Constr. Steel Res. 2008, 64, 1199-1206.

10. Gedge G. Structural uses of stainless steel buildings and civil engineering. J. Constr, Steel Res. 2008, 64, 1194-1198.
11. Magudeeswaran G., Nair S.R., Sundar L., Harikannan N. Optimization of process parameters of the activated tungsten inert gas welding for aspect ratio of UNS S32205 duplex stainless steel welds. Def. Technol. 2014, 10, 251-260.

12. Bobbili R., Madhu V., Gogia A.K. Neural network modeling to evaluate the dynamic flow stress of high strength armor steels under high strain rate compression. Def. Technol. 2014, 10, 334-342.

13. Magudeeswaran G., Balasubramanian V., Madhusudhan Reddy G. Effect of welding processes and consumables on fatigue crack growth behaviour of armour grade quenched and tempered steel joints. Def. Technol. 2014, 10, 47-59.

14. Reis G.S., Jr A.M.J., Balancin O. Influence of the microstructure of duplex stainless steels on their failure characteristics during hot deformation, 2 . Materials and experimental procedures. Mater. Res. 2000, 3, 31-35.

15. Domínguez-Aguilar M., Newman R.C. Detection of deleterious phases in duplex stainless steel by weak galvanostatic polarization in alkaline solution. Corros. Sci. 2006, 48, 2560-2576.

16. Zucato I., Moreira M.C., Machado I.F., Giampietri S.M. Microstructural characterization and the effect of phase transformations on toughness of the UNS S31803 duplex stainless steel aged treated at $850{ }^{\circ} \mathrm{C}$. Mater. Res. 2002, 5, 385-389.

17. Liou H., Pan Y., Hsieh R., Tsai W. Effects of alloying elements on the mechanical properties and corrosion behaviors of 2205 duplex stainless steels. JMEPEG 2001, 10(2), 231-241.

18. Gunn R., (Ed.) Duplex stainless steels: microstructure, properties and applications. Elsevier, 1997.

19. Sathiya P., Aravindan S., Soundararajan R., Noorul Haq A. Effect of shielding gases on mechanical and metallurgical properties of duplex stainlesssteel welds. J. Mater. Sci. 2008, 44, 114-121.

20. Tan H., Jiang Y., Deng B., Sun T., Xu J., Li J. Effect of annealing temperature on the pitting corrosion resistance of super duplex stainless steel UNS S32750. Mater. Charact. 2009, 60, 1049-1054.

21. Deng B., Wang Z., Jiang Y., Sun T., Xu J., Li J. Effect of thermal cycles on the corrosion and mechanical properties of UNS S31803 duplex stainless steel. Corros. Sci. 2009, 51, 2969-2975.

22. Potgieter J.H., Olubambi P.S., Cornish L, Machio C.N., Sherif E.-S.M. Influence of nickel additions on the corrosion behaviour of low nitrogen $22 \% \mathrm{Cr}$ series duplex stainless steels. Corros. Sci. 2008, 50, 2572-2579.

23. Hanninen H., Romu J., Ilola R., Tervo J., Laitinen A. Effects of processing and manufacturing of high nitrogen-containing stainless steels on their mechanical, corrosion and wear properties. J. Mater. Process. Technol. 2001, 117, 424-430. 
24. Lothongkum G., Wongpanya P., Morito S., Furuhara T., Maki T. Effect of nitrogen on corrosion behavior of $28 \mathrm{Cr}-7 \mathrm{Ni}$ duplex and microduplex stainless steels in air-saturated $3.5 \mathrm{wt} \% \mathrm{NaCl}$ solution. Corros. Sci. 2006, 48, 137-153.

25. Huang C.S., Shih C.C.. Effects of nitrogen and high temperature aging on $\sigma$ phase precipitation of duplex stainless steel. Mater. Sci. Eng. A, 402, 2005, 66-75.

26. Toor I.-H., Hyun P.J., Kwon H.S. Development of high Mn-N duplex stainless steel for automobile structural components. Corros. Sci. 50, 2008, 404-410.

27. Krawiec H, Vignal V, Heintz O, Oltra R. Influence of the dissolution of MnS inclusions under free corrosion and potentiostatic conditions on the composition of passive films and the electrochemical behaviour of stainless steels. Electrochim Acta 2006, 51, 3235-3243.

28. Banas J, Mazurkiewicz A. The effect of copper on passivity and corrosion behaviour of ferritic and ferritic - austenitic stainless steels. Mater. Sci. Eng. A 2000, 277, 183-191.

29. Karlsson L. Intermetallic phase precipitation in duplex stainless steels and weld metals: Metallurgy, influence on properties, welding and testing aspects. 1999.

30. García-García D.M., García-Antón J., Igual-Muñoz A., Blasco-Tamarit E. Effect of cavitation on the corrosion behaviour of welded and non-welded duplex stainless steel in aqueous $\mathrm{LiBr}$ solutions. Corros. Sci. 2006, 48, 2380-2405.

31. Yang Y., Wang Z., Tan H., Hong J., Jiang Y., Jiang L, et al. Effect of a brief post-weld heat treatment on the microstructure evolution and pitting corrosion of laser beam welded UNS S31803 duplex stainless steel. Corros. Sci. 2012, 65, 472-480.

32. Pekkarinen J., Kujanpää V. The effects of laser welding parameters on the microstructure of ferritic and duplex stainless steels welds. Phys. Procedia 2010, 5, 517-523.

33. Migiakis K., Papadimitriou G.D. Effect of nitrogen and nickel on the microstructure and mechanical properties of plasma welded UNS S32760 superduplex stainless steels. J. Mater. Sci. 44, 2009, 6372-6383.

34. Pettersson C., Sven-Åke Fager. Welding practice for the Sandvik duplex stainless steels SAF 2304, SAF 2205 and SAF 2507. Sandvik Steel 1994; S-881, 1-14.

35. Tavara S.A., Chapetti M.D., Otegui J.L., Manfredi C. Influence of nickel on the susceptibility to corrosion fatigue of duplex stainless steel welds. Int. J. Fatigue 2001, 23, 619-626.

36. Capello E., Chiarello P., Pre B., Vedani M. Laser welding and surface treatment of a $22 \mathrm{Cr}-5 \mathrm{Ni}-3 \mathrm{Mo}$ duplex stainless steel. Mater. Sci. Eng. A 2003, 351, 334-343.

37. Karlsson L., Proceedings of the International Conference Duplex America 2000, Houston, USA, KCI Publisher, 2000, p. 43.

38. Hsieh C-C, Wu W. Overview of intermetallic sig$\mathrm{ma}(\sigma)$ phase precipitation in stainless steels. ISRN Metall. 2012, 1-16.

39. Sieurin H., Sandström R.. Sigma phase precipitation in duplex stainless steel 2205. Mater. Sci. Eng. A 2007, 444, 271-276.

40. Magnabosco R. Kinetics of sigma phase formation in a duplex stainless steel, 2. Experimental procedure. Mater. Res. 2009, 12, 321-327.

41. Pohl M., Storz O., Glogowski T. Effect of intermetallic precipitations on the properties of duplex stainless steel. Mater. Charact. 2007, 58, 65-71.

42. Martins M., Casteletti L.C. Sigma phase morphologies in cast and aged super duplex stainless steel. Mater. Charact. 2009, 60, 792-795.

43. Chen T.H, Yang J.R. Effects of solution treatment and continuous cooling on $\sigma$-phase precipitation in a 2205 duplex stainless steel. Mater. Sci. Eng. A 2001, 311, 28-41.

44. Sieurin H., Sandström R. Austenite reformation in the heat-affected zone of duplex stainless steel 2205. Mater. Sci. Eng. A 2006, 418, 250-256.

45. Martins M., Casteletti L.C. Microstructural characteristics and corrosion behavior of a super duplex stainless steel casting. Mater. Charact. 60, 2009, 150-155.

46. Escriba D.M, Materna-Morris E., Plaut R.L., Padilha A.F. Chi-phase precipitation in a duplex stainless steel. Mater Charact 2009;60:1214-1219.

47. Michalska J, Sozańska M. Qualitative and quantitative analysis of $\sigma$ and $\chi$ phases in 2205 duplex stainless steel. Mater. Charact. 2006, 56, 355-362.

48. Yuko D., Wolynec S.. Evaluation of the low corrosion resistant phase formed during the sigma phase precipitation in duplex stainless steels. Mater. Res. 1999, 2, 239-247.

49. Ramirez A.J., Lippold J.C., Brandi S.D. The relationship between chromium nitride and secondary austenite precipitation in duplex stainless steels. Metall. Mater. Trans. A 2003, 34A, 1575-1597.

50. Cui J., Park I., Kang C., Miyahara K. Degradation of impact toughness due to formation of $r$ phase in high nitrogen 25Cr-7Ni-Mo duplex stainless steels. ISIJ Int. 2001, 41, 192-195.

51. Hwang T.H., Kim J.H., Kim K.H., Moon W.J., Kang C.Y. Effect of R-phase on impact toughness of 25Cr-7Ni-4Mo super duplex stainless steel. Met. Mater. Int. 2014, 20, 13-17.

52. Lo K.H., Shek C.H., Lai J.K.L. Recent developments in stainless steels. Mater. Sci. Eng. A 2009, 65, 39-104. 
53. Sahu J.K., Krupp U., Ghosh R.N., Christ H.-J. Effect of $475^{\circ} \mathrm{C}$ embrittlement on the mechanical properties of duplex stainless steel. Mater. Sci. Eng. A, 2009, 508, 1-14.

54. Deng B., Wang Z., Jiang Y., Wang H., Gao J., Li J. Evaluation of localized corrosion in duplex stainless steel aged at $850^{\circ} \mathrm{C}$ with critical pitting temperature measurement. Electrochim. Acta 2009, 54, 2790-2794.

55. Merello R., Botana F.J., Botella J., Matres M.V., Marcos M. Influence of chemical composition on the pitting corrosion resistance of non-standard low-Ni high-Mn - N duplex stainless steels. Corros. Sci. 2003, 45, 909-921.

56. Cervo R., Ferro P., Tiziani A., Zucchi F. Annealing temperature effects on superduplex stainless steel UNS S32750 welded joints. II. Pitting corrosion resistance evaluation. J. Mater. Sci. 2010, 45, 4378-4389.

57. Dobrzański L.A., Brytan Z., Grande M.A., Rosso M., Pallavicini E.J. Properties of vacuum sintered duplex stainless steels. J. Mater. Process. Technol. 162-163, 2005, 286-292.

58. Park C.J., Rao V.S., Kwon H.S. Effects of sigma phase on the initiation and propagation of pitting corrosion of duplex stainless steel. Corrosion 2005, 61, 76-83.

59. Fargas G., Anglada M., Mateo A. Effect of the annealing temperature on the mechanical properties, formability and corrosion resistance of hot-rolled duplex stainless steel. J. Mater. Process. Technol. 2009, 209, 1770-1782.

60. Luo H., Li X.G., Dong C.F., Xiao K. Effect of solution treatment on pitting behavior of 2205 duplex stainless steel. Arab. J. Chem. 2012, 1-5.

61. Ezuber H.M., El-Houd A., El-Shawesh F. Effects of sigma phase precipitation on seawater pitting of duplex stainless steel. Desalination 2007, 207, 268-275.

62. Wilms M.E., Gadgil V.J., Krougman J.M., Ijsseling F.P. The effect of $\sigma$-phase precipitation at $800^{\circ} \mathrm{C}$ on the corrosion resistance in sea-water of a high alloyed duplex stainless steel. Corros. Sci. 36, 1994, 871-881.

63. Igual-Muñoz A., García-Antón J., Guinon J.L., Perez Herranz V. Inhibition effect of chromate on the passivation and pitting corrosion of a duplex stainless steel in LiBr solutions using electrochemical techniques. Corros. Sci. 2007, 49, 3200-3225.

64. Ebrahimi N., Momeni M., Kosari A., Zakeri M., Moayed M.H. A comparative study of critical pitting temperature (CPT) of stainless steels by electrochemical impedance spectroscopy (EIS), potentiodynamic and potentiostatic techniques. Corros. Sci. 2012, 59, 96-102.

65. Palmer T., Elmer J., Babu S. Observations of ferrite/austenite transformations in the heat affected zone of 2205 duplex stainless steel spot welds using time resolved X-ray diffraction. Mater. Sci. Eng. A 2004, 374, 307-321.

66. Ogawa T., Koseki T. Effect of composition profiles on metallurgy and corrosion behavior of duplex stainless steel weld metals. Weld J. 1989, 68, 181.

67. Barnhouse E.J., Lippold J.C. Microstructure / property relationships in dissimilar welds between duplex stainless steels and carbon steels. Weld Journal, New York 1998, 77, 477-458.

68. Yousefieh M., Shamanian M., Saatchi A. Influence of step annealing temperature on the microstructure and pitting corrosion resistance of SDSS UNS S32760 Welds. J. Mater. Eng. Perform 2011, 20, 1678-1683.

69. Shin Y.T., Shin H.S., Lee H.W. Effects of heat input on pitting corrosion in super duplex stainless steel weld metals. Met. Mater. Int. 2012, 18, 1037-1040.

70. Cervo R., Ferro P., Tiziani A., Zucchi F. Annealing temperature effects on superduplex stainless steel UNS S32750 welded joints. II: Pitting corrosion resistance evaluation. J. Mater. Sci. 2010, 45, 4378-4389.

71. Cervo R., Ferro P., Tiziani A. Annealing temperature effects on super duplex stainless steel UNS s32750 welded joints. I: Microstructure and partitioning of elements. J. Mater. Sci. 2010, 45, 4369-4377.

72. Prohaska M., Wernig T., Perek J., Mori G., Tischler G., Grill R. Application of the DL-EPR - method for detecting sensitization to intergranular corrosion in thermomechanically rolled corrosion-resistant alloys 316L , 825L and 926L n.d., 1-8.

73. Chan K., Tjong S. Effect of secondary phase precipitation on the corrosion behavior of duplex stainless steels. Materials (Basel) 2014, 7, 5268-5304.

74. Amadou T., Braham C., Sidhom H. Double loop electrochemical potentiokinetic reactivation test optimization in checking of duplex stainless steel intergranular corrosion susceptibility. Metall. Mater. Trans. A 2004, 35A, 3499-3513.

75. Ortiz N., Curiel F.F., López V.H, Ruiz A. Evaluation of the intergranular corrosion susceptibility of UNS S31803 duplex stainless steel with thermoelectric power measurements. Corros. Sci. 2013, 69, 236-244.

76. Hong J., Han D., Tan H., Li J., Jiang Y. Evaluation of aged duplex stainless steel UNS S32750 susceptibility to intergranular corrosion by optimized double loop electrochemical potentiokinetic reactivation method. Corros. Sci. 2013, 68, 249-255.

77. Deng B., Jiang Y., Xu J., Sun T., Gao J., Zhang L, et al. Application of the modified electrochemical potentiodynamic reactivation method to detect susceptibility to intergranular corrosion of a newly developed lean duplex stainless steel LDX2101. Corros. Sci. 2010, 52, 969-977. 
78. Gong J., Jiang Y.M., Deng B., Xu J.L., Hu J.P., Li J. Evaluation of intergranular corrosion susceptibility of UNS S31803 duplex stainless steel with an optimized double loop electrochemical potentiokinetic reactivation method. Electrochim Acta 2010, 55, 5077-5083.

79. Lopez N., Cid M., Puiggali M. Infuence of $\sigma$-phase on mechanical properties and corrosion resistance of duplex stainless steels. Corros. Sci. 1999, 41, 1615-1631.

80. Lo K.H., Kwok C.T., Chan W.K., Zeng D. Corrosion resistance of duplex stainless steel subjected to long-term annealing in the spinodal decomposition temperature range. Corros. Sci. 2012, 55, 267-271.

81. Tsai W., Chen M. Stress corrosion cracking behavior of 2205 duplex stainless steel in concentrated $\mathrm{NaCl}$ solution. Corros. Sci. 2000, 42, 545-559.

82. EL-Yazgi A.A., Hardie D. Stress corrosion cracking of duplex and super duplex stainless steels in sour environments. Corros. Sci. 1998, 40, 909-930.

83. Olden V., Thaulow C., Johnsen R. Modelling of hydrogen diffusion and hydrogen induced cracking in supermartensitic and duplex stainless steels. Mater. Des. 2008, 29, 1934-1948.

84. Young M.C., Chan S.L.I., Tsay L.W., Shin C.-S. Hydrogen-enhanced cracking of 2205 duplex stainless steel welds. Mater. Chem. Phys. 2005, 91, 21-27.

85. Olden V., Thaulow C., Johnsen R., Østby E. Cohesive zone modeling of hydrogen-induced stress cracking in $25 \% \mathrm{Cr}$ duplex stainless steel. Scr. Mater. 2007, 57, 615-618.
86. Chou S., Tsai W. Effect of grain size on the hydrogen-assisted cracking in duplex stainless steels. Mater. Sci. Eng. A 1999, 270, 219-224.

87. Stainless D., Weld S. Hydrogen cracking in duplex stainless steel weld metal. Weld Journal 1992, 71, 387-396.

88. Badji R., Bouabdallah M., Bacroix B., Kahloun C., Bettahar K., Kherrouba N. Effect of solution treatment temperature on the precipitation kinetic of $\sigma$-phase in 2205 duplex stainless steel welds. Mater. Sci. Eng. A 2008, 496, 447-454.

89. Topolska S., Labanowski J. Effect of microstructure on impact toughness of duplex and superduplex stainless steels. J. Achiev. Mater. Manuf. Eng. 2009, 36, 142-149.

90. Børvik T., Marken L.A., Langseth M., Rørvik G., Hopperstad O.S. Influence of sigma-phase precipitation on the impact behaviour of duplex stainless steel pipe fittings. Ships Offshore Struct. 2014, 1-13.

91. Karlsson L, Ryen L, Pak S. Precipitation of intermetallic phases in $22 \% \mathrm{Cr}$ duplex stainless weld metals. Weld Journal Including Weld Res. Suppl. 1995, 74, 28-40.

92. Martins M., Casteletti L.C. Effect of heat treatment on the mechanical properties of A 890 Gr6A super duplex stainless steel. J. ASTM Int. 2005, 2, 1-14.

93. Li J., Wu T., Riquier Y. A phase precipitation and its effect on the mechanical properties of a super duplex stainless steel. Mater. Sci. Eng. A 1994, 174, 149-156. 